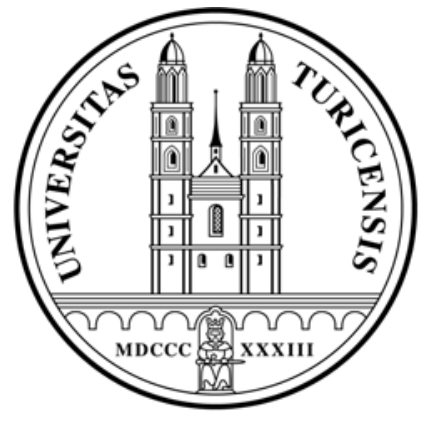

Institute for Empirical Research in Economics

University of Zurich

Working Paper Series

ISSN 1424-0459

Working Paper No. 454

\title{
Information Sharing and Information Acquisition in Credit Markets
}

Artashes Karapetyan and Bogdan Stacescu

November 2009 


\title{
Information Sharing and Information Acquisition in Credit Markets
}

\author{
Artashes Karapetyan \\ University of Zurich \\ and \\ Bogdan Stacescu \\ BI Norwegian School of Management*
}

November 16, 2009

\begin{abstract}
Since information asymmetries have been identified as an important source of bank profits, it may seem that the establishment of information sharing will lead to lower investment in acquiring information. However, banks base their decisions on both hard and soft information, and it is only the former type of data that can be communicated credibly. We show that when hard information is shared, banks will invest more in soft, relationship-specific information. These will lead to more accurate lending decisions, favor small, informationally opaque borrowers, and increase welfare. Since relationship banking focuses on the usage of soft information, the model implies that investment in relationship banking will increase. We test our theory using a large sample of firm-level data from 24 countries.

Keywords: Bank competition, information sharing, relationship banking, hard information, soft information

JEL classification numbers: G21, L13
\end{abstract}

*We would like to thank Efraim Benmelech, Lamont Black, Hans Degryse (discussant), Christian Ewerhart, Michel Habib, Jeremy Stein, Oliver Hart, Gustavo Manso (discussant), Lars Norden, as well as seminar participants at the Western Finance Association (2009), Finrisk Research Day in Gerzensee (2009), Banking and Financial Intermediation Conference in Hasliberg (2009), Symposium of Economic Analysis (2008), Harvard Organizational Economics Seminar(2008) and Washington Finance Association(2008) for their helpful comments. We thank National Bank of Hungary for financial support. 


\section{Introduction}

The importance of financial intermediaries in the production of information has long been recognized. ${ }^{1}$ Information provides competitive advantage and is an important source of bank profits. However, the production and availability of information have been significantly affected in the changing industry, which in recent years has seen the entry of information sharing institutions, such as credit bureaus and credit registers. Will these changes level the playing field among banks and distort information acquisition? We argue, that such changes increase banks' incentives to acquire information, make more accurate credit decisions, earn higher rents and increase welfare.

To study these issues, we start from an important distinction between two types of information: "hard" information that can be shared, and "soft" information that cannot be shared credibly (Stein 2002, Berger et al 2005). We extend a two-period banking competition model based on von Thadden (2004). In each period two banks compete in interest rates for borrowers of high and low credit quality. Borrowers choose the best quote, and if offers are identical, allocate themselves randomly. In period 1, banks compete for banking relationships based on symmetric information. Each bank wins a certain market share and extends credit to its borrowers. At the end of period 1 borrowers repay if they can, and each "informed" bank faces two groups of its own borrowers: defaulting borrowers, and successful borrowers (those who have repaid). This information is hard, and can be shared with the "uninformed" bank under an information sharing regime. Because default information does not reveal borrower's true type (e.g., borrowers default due to bad luck), each bank may want to invest in the monitoring of its own borrowers during first-period lending. ${ }^{2}$ The outcome of monitoring is a signal about the borrower's true type: good or bad. This information is "soft". For second period lending, therefore, the informed bank differentiates borrowers based on two sources of information: hard information - default or success of its borrower, and soft information - good or bad signal. Monitoring is costly, but provides further rents for the bank: in particular, if the monitoring signal is precise enough, bad signal borrowers are likely to be uncreditworthy, and banks can avoid losses by rejecting credit to them. Such costly monitoring provides higher marginal returns for the defaulting group of borrowers, since uncreditworthy borrowers are more likely to have defaulted.

In the lending competition, borrowers from all groups may switch their banks. While soft information cannot be shared with the uninformed bank, hard information can be shared under an information sharing regime. If it is shared, the uninformed bank becomes less aggressive with respect to defaulting group, as it learns now about their default. On the contrary, under no information sharing, the uninformed bank

\footnotetext{
${ }^{1}$ See, for example, Sharpe (1990), von Thadden 2004).

${ }^{2}$ We analyze our model where information is acquired during ex-ante screening as well, and the results are qualitatively similar. We do not present for brevity.
} 
is more aggressive with respect to the defaulting group, since they are pooled with successful borrowers, who have higher average quality.

For the same reason,successful borrowers get more aggressive bids under information sharing. As a result, under information sharing regime defaulting borrowers are more likely to stay with the inside bank, while successful borrower -more likely to switch. Because monitoring provides higher marginal returns on defaulting borrowers, the inside bank will acquire more soft information under the information sharing regime. Hence, banks will evaluate borrowers more accurately and will be able to avoid true bad risks more often. As a result of this saving, banks informational rents in period 2 may increase. Moreover, we show how higher competition for banking relationships under information sharing will benefit the creditworthy borrowers. Banks and borrowers win overall, and welfare increases.

These are our core findings, that also shape our main policy implication. They show the concern that sharing information will erode rents, lead to insufficient information acquisition, and may thus decrease welfare, is not true. Interventions to support establishing information sharing are welfare improving.

Our findings have an important implication for relationship banking. Information sharing allows the uninformed bank to learn about default and successful repayments. Successful customers thus enjoy a more competitive environment, can switch safely: these are the "transactional" customers. However defaulting customers are less likely to switch. However, if they have defaulted due to bad luck, the informed bank can reveal this by long-standing information acquisition and create value by good soft signals: these are the "relationship" customers. In effect, this will increase size and importance of the relationship bank, and more bad types will be identified by the informed bank's unique ability of gathering relationship-specific information.

The results provide a crucial insight for small business lending. The magnitude of the investment in relationship information depends on the level of asymmetric information that it is supposed to overcome; if there is no asymmetric information, there is no payoff to the investment. This means information sharing will generate a larger impact on small firms: information about small firms from public sources is scarce, as most of them do not have audited financial statements, are not rated by rating agencies, and therefore information asymmetries are most acute for small firms (Petersen and Rajan 2004). We derive the theoretical prediction and support it empirically.

The information sharing institution we are studying is not confined to credit bureaus and public registers. ${ }^{3}$ In particular, our findings are applicable for borrower's interaction with its bank before and after an initial public offering (IPO). During the IPO, a considerable amount of information is revealed, and the firm is held accountable by the Securities Exchange Commission (SEC) for its reporting. Moreover, after the IPO the firm must comply with ongoing disclosure requirements mandated by the SEC

\footnotetext{
${ }^{3}$ Hauswald and Marquez (2003) analyze other implications of accessing to the incumbent's information for the insurance and securities markets.
} 
and the stock exchange where its shares trade. Prior to the IPO, however, firms are not required to release information. We imply that banks should deploy higher relationship intensity for IPO firms, especially if the firms are small and informationally opaque. Such implications are in line with recent finding on the informativeness of bank loan agreements for IPO borrowers. Using data on U.S. firm from Dealscan and Securities Data corporation, Sokolyk (2009) finds that IPO firms borrow 1.7 as much on average as they raise at the IPO, and bank loan agreements are associated with higher stock returns for small, opaque IPO borrowers than for large ones.

Our findings point to an interesting implication in terms of the structure of the banking system. In particular, information sharing may widen the gap between small banks relying on collecting relationship, soft information and large banks relying on standardized, hard information (Stein (2002), Berger et al. (2005)): indeed, information sharing increases returns to collecting relationship information for small banks, and makes it easier for large banks to get their standardized data.

The paper goes on to analyze implications for interest rates and switching. We show that the intuition that information sharing will facilitate switching by leveling informational sets, is premature. If defaulting borrowers dominate in the market, switching may in fact decrease under information sharing. On the other hand, if lenders try to squeeze the borrowers too much due to higher monitoring, borrowers may eventually want to switch more, and this effect may dominate. Overall results are mixed.

Moreover, we find that that information sharing need not unilaterally decrease interest rates. Previous research in this are has shown that information sharing decreases interest rates (Brown et al 2007, Jappeli and Pagano 2002). Due to lack of data, empirical evidence has scarcely taken into account borrower heterogeneity. Curiously, Doblas-Madrid and Minetti (2009) show that entering a credit bureau reduces access to finance for borrowers who have high debt exposure and are therefore more likely to default.We find theoretically that information sharing increases rates for borrowers with default, and decreases rates for successful ones.

For our empirical analysis, we use data on firms and information sharing arrangements from 24 transition countries. We analyze the impact of introducing private credit bureaus and public credit registries sharing hard information on the lenders' incentives to invest more in soft information. Specifically, we test and confirm that information acquisition is higher in countries with an established information sharing. Furthermore, using firm-level data allows us to test and confirm that the impact is indeed stronger for small firms.

Recent literature has focused on the implications of information sharing from a different angle. Padilla and Pagano (1997) show how information sharing may provide borrowers with higher incentives to perform: because information becomes available to competitor banks, banks will not be able to appropriate informational rents. Similarly, borrowers may perform better since otherwise default will become known to all banks, 
and may hinder future access to finance (Padilla and Pagano 2000). In an adverse selection setup, information sharing allows banks to learn the types of the borrowers who exogenously switch from their competitors, and banks earn rents on good borrowers (Jappeli and Pagano 1993). In contrast, our goal is to focus on the link between (hard) information sharing and (soft) information acquisition. This interaction, to the best of our knowledge, has not been studied before.

The remainder of the article is organized as follows. Section 2 presents a model of banking competition and information acquisition. We first derive the equilibrium of the banking competition with and without information sharing (subsection 2.2 and 2.3). We then look at interest rates, switching and welfare (subsections 2.4, 2.5, and 2.6). Section 3 provides empirical evidence, and section 4 concludes. Proofs are mostly relegated to the Appendix.

\section{The Model}

We model the interaction between banks and borrowers over two periods. At the starting point, banks have symmetric information about the average ex-ante risk of borrower population. During the lending relationship, each bank acquires both default and relationship information about those borrowers who contracted with it previously. Following Petersen and Rajan 2004, Stein 2002, we call the former hard and the latter soft information. ${ }^{4}$ We call this the informed bank: it acquires soft information by investing in monitoring technology and observes the hard data-whether or not borrowers managed to repay their loans.

We study two environments: without information sharing, both types of information are unavailable to competitors -the uninformed bank. These provide informational rents for the informed bank.

When information is shared, the success or default of each borrower becomes known to the uninformed bank. The soft information, however, cannot be shared and continues to generate a competitive advantage for informed bank.

\subsection{The Setup}

There are two banks and a continuum of borrowers in $[0,1]$ who are active for two periods. In each period, each borrower has access to an investment project that requires $\$ I$. Because they have no initial wealth, they borrow the money from one of the two banks.

There are two types of borrowers:

\footnotetext{
${ }^{4}$ We use default information here, since it is the most basic type of hard information and also the most commonly shared. Hard information can also obviously be any type of information that can be shared by means of a credit bureau.
} 
- High-type borrowers represent a proportion $\lambda$ in the overall population. They have a probability $p(0<p<1)$ of producing a terminal cash flow $R>0$, and large enough to repay principal and interest rates. With probability $1-p$ they produce $0 .{ }^{5}$

- Low-type borrowers represent a proportion $1-\lambda$ in the overall population and they always fail, yielding 0 .

The final cash flows are observable and contractible by the current lender. Under information sharing, the return is observable also to the uninformed lender. The proportions of borrowers and the success probabilities are common knowledge. Borrowers have identical (and independent) projects, no initial funds in both periods and are protected by limited liability. As in vcon Thadden (2004), borrowers do not know their own types. ${ }^{6}$ Banks can raise capital at a gross interest rate 1 and compete in interest rates given their respective information sets. They offer one period contracts. 7 At the beginning of the first period, without any previous contact with the potential customers, banks only know the average risk of the population. As a result, they offer the same interest rate to all applicants.

During the first period banks can acquire information about their borrowers by monitoring them. The monitoring process begins after the first period loans have been extended. It results in a signal $\eta$ of borrowers' types. The quality of the signal is given by $\varphi$ :

$$
\begin{gathered}
\operatorname{Pr}(\eta=G \mid \text { type }=H)=\operatorname{Pr}(\eta=B \mid \text { type }=L)=\varphi>\frac{1}{2} \\
\operatorname{Pr}(\eta=B \mid \text { type }=L)=\operatorname{Pr}(\eta=B \mid \text { type }=H)=1-\varphi .
\end{gathered}
$$

Thus, at the end of the first period banks have two types of information about their borrowers:

- the signal generated by monitoring, $\eta=G$ or $\eta=B$;

- the repayment history - i.e., whether borrowers have defaulted or not, $h=D$ or $h=N$.

The signal is costly: getting a signal of quality $\varphi$ requires an outlay of

\footnotetext{
${ }^{5}$ We assume a project's output cannot be stored, so that it does not generate resources for operations in the second period

${ }^{6}$ Alternatively, we could assume there are no sorting devices such as collateral, since, for example, the borrower has no wealth.

${ }^{7}$ As shown in Sharpe (1990), this absence is the interesting case to consider, since otherwise the analysis would reduce to standard competitive pricing and miss the important point in bank relationships (see also von Thadden 2004).
} 


$$
c(\varphi)=c\left(\varphi-\frac{1}{2}\right)^{2}
$$

We call $\varphi$ informativeness of monitoring. As a result, banks have to decide how much to invest in the monitoring technology. The default information and information resulting from monitoring can be used by banks to update their estimate of the borrowers' types and adjust their interest rates for the second period.

While default information is verifiable, the outcome of the monitoring process is "soft" information by assumption: it is prohibitively costly to communicate this information between banks. As a result, a credit bureau is only able to collect and share default information, and each bank will know which of the other bank's initial customers has defaulted. Without a credit bureau, both default and monitoring information are only available to incumbent banks.

Thus, incumbent banks can distinguish between three types among their first-period customers:

- borrowers that have defaulted and have also generated a bad signal when monitored;

- borrowers that have defaulted, but have generated a good signal when monitored;

- borrowers that have not defaulted (but generated either a good signal or a bad signal when monitored).

We assume that $p_{D} R>I$, where $p_{D}=P(h=D)$ is the success probability given the borrower has defaulted.

$$
p_{D}=\frac{\lambda p(1-p)}{\lambda(1-p)+(1-\lambda)} .
$$

This means it is efficient to grant a loan to defaulters. ${ }^{8}$ As a result, banks can resort to discriminatory pricing through their interest rate offers as a function of the default history and the informativeness. The first type is obviously the least likely to produce a positive return in the second period, while the last one is the most likely to be successful.

Note, that our setup allows for the relationship scope of the banking firm: relationship lending allows informationally opaque firms with weak financial ratios, collateral, or credit scores to obtain loans by augmenting the weak hard information with good soft information gained through closer contacts over time (Berger and Udell (2002)). Indeed, if some of the borrowers are actually good who are just unlucky (our second group above), relying too much on the hard information provided by past defaults

\footnotetext{
${ }^{8}$ Obviously, it implies it is ex-ante efficient to grant a loan to an average risk.
} 
could lead to welfare losses (Jappelli and Pagano (2000), Berger and Udell (2002)). ${ }^{9}$ Those who have not defaulted, are certainly good borrowers by assumption. Therefore the signal is not crucial, and banks can lend them safely based only on hard data. We therefore group them all together.

In the next two subsections we describe the equilibrium strategies of the informed and uninformed banks under information sharing, and no information sharing, respectively.

\subsection{Default information is shared}

We start with the case where information is shared in the economy. The actions taken by the banks and borrowers are outlined below.

\section{The timing of the game}

$$
T=1
$$

- Banks announce one term lending rates and compete à la Bertrand.

- Borrowers choose one of the banks with equal probability and invest $I$.

- Banks invest in monitoring.

- Borrowers repay whenever they can do so.

$$
T=2
$$

- Banks share payment/default history (hard information).

- Simultaneously the informed and the uninformed banks offer second period interest rates. Each bank has two types of information about its first period borrowers, and has received default information concerning its competitor's borrowers.

- The firm chooses an offer and invests $I$. If indifferent, the firm chooses the bank randomly. ${ }^{10}$

- Borrowers repay/ do not repay their loans, banks' payoffs are realized.

\subsubsection{Preliminary steps}

We first derive a borrower's success probability in light of the each bank's credit assessments based on their information sets. The informational advantage of the informed and the uninformed bank are depicted in Figure 1.

If default information is shared, both the uninformed and the informed bank will learn which borrowers have been successful in the first period. Both banks will therefore

\footnotetext{
${ }^{9}$ Algebraically, this amounts to the assumption we will make: the good signal defaulting borrowers are creditworthy, while the bad signal ones - are not, $p_{G D} R>I$.

${ }^{10}$ If there is only one offer, the firm takes it. If no offer, the firm does not get credit. We will see in the equilibrium that this may be the case when bad signal defaulting borrowers are not creditworthy.
} 
Informed

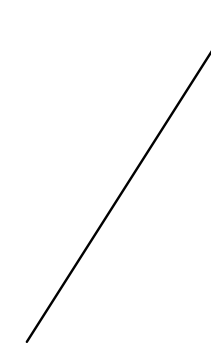

$\mathrm{N}$

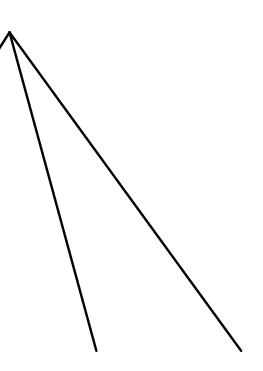

GD BD
Uninformed

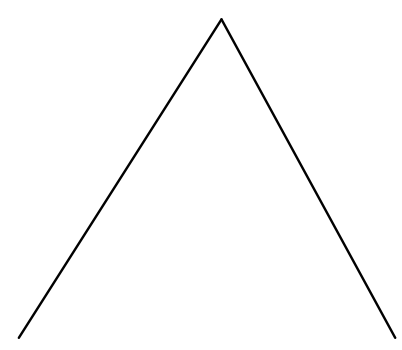

$\mathrm{N}$
$\mathrm{D}$

Figure 1: Borrower groups for the informed and the uninformed banks under information sharing

learn the successful borrower's true type: because low ability borrowers never succeed, (bad) signal from monitoring is no longer important.

Based on the acquired information and the initial data on the population, banks are able to update borrowers' success probabilities and use this to determine their interest rates. Both banks can condition their rates on default information, but only the incumbent bank can also use the soft information to differentiate the interest rates that it offers to its first-period borrowers.

Denoting $p_{G D}=P(\eta=G, h=D)$ the success probability when the borrower has produced signal $G$ and history $D$ (and following similar notations), the Bayesian updated probabilities of success are given by:

$$
\begin{aligned}
p_{N} & =p ; \\
p_{G D} & =\frac{\lambda \varphi p(1-p)}{\lambda \varphi(1-p)+(1-\lambda)(1-\varphi)} \\
p_{B D} & =\frac{\lambda(1-\varphi) p(1-p)}{\lambda(1-\varphi)(1-p)+(1-\lambda) \varphi}
\end{aligned}
$$

four the three types, and

$$
\begin{aligned}
p_{D} & =\frac{\lambda p(1-p)}{\lambda(1-p)+(1-\lambda)} \\
\bar{p} & =\lambda p
\end{aligned}
$$

for defaulting and the overall universe of borrowers respectively. 
From Bayesian rules, better types have higher updated probabilities. We define the respective break-even gross interest rate for each of the groups to be equal to the investment $I$ divided by the respective probability, $\bar{r}_{K}=\frac{I}{p_{K}}$, for $K=D, N, G D$ or $B D$, while for the overall population it is equal to $\bar{r}=\frac{I}{\bar{p}}=\frac{I}{\lambda p}$. The break-even interest rates will obviously be lower for better types. The rates are depicted in figure 3 .

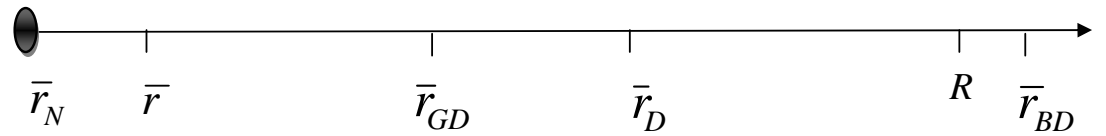

Figure 2: Interest rates-no information sharing

We define $\bar{\varphi}$ such that $R p_{B D}=I$. That is, whenever $\varphi>\bar{\varphi}$, bad signal defaulting borrowers are not creditworthy. Thus, when $\varphi>\bar{\varphi}$ the incumbent will not bid for uncreditworthy $B D$ group. Below we analyze the equilibrium in both cases.

\subsubsection{Lending Competition}

Banks move simultaneously to bid second period interest rates, and thus do not observe each other's rates. Uninformed banks do not know the signals borrowers received. As showed in von Thadden (2004), there is no pure strategy equilibrium in simultaneous-bid games where one lender knows more than the other. This is a known result from the literature on auctions (Milgrom and Weber 1982). There is however a mixed-strategy equilibrium in which banks randomize over intervals of interest rates. The second period of the game thus has a mixed-strategy Perfect Bayesian Nash equilibrium, the properties of which we analyze below.

Each bank has five interest rate strategies: Let the cumulative density function $F_{u}^{K}(r)$ denote the probability that the uninformed bank chooses an interest rate less or equal to $r$ for defaulting $(K=D)$ and non-defaulting $(K=N)$ borrowers respectively. $F_{i}^{J}(r)$ describes the bidding strategies for the informed bank for the good-signal defaulting $(J=G D)$, bad-signal defaulting $(J=B D)$ and the non-defaulting $(J=N)$ borrowers.

For any interest rate for a given group, the informed bank will make a non-negative profit provided it has not been undercut by the competing bank. Thus the profit functions for the three types can be expressed as follows: 


$$
\begin{aligned}
\pi_{i}^{N}(r) & =0 \\
\pi_{i}^{G D}(r) & =N_{G D}\left(p_{G D} r-I\right)\left(1-F_{u}^{D}(r)\right) \\
\pi_{i}^{B D}(r) & =N_{B D}\left(p_{B D} r-I\right)\left(1-F_{u}^{D}(r)\right)
\end{aligned}
$$

where $N_{G D}, N_{B D}$ denote the expected number of the respective borrower group. The uninformed bank's profits on the two types it can distinguish (defaulters and non-defaulters) will be:

$$
\begin{aligned}
\pi_{u}^{D}(r)=N_{G D}\left(p_{G D} r-I\right)\left(1-F_{i}^{G D}(r)\right)+N_{B D}\left(p_{B D} r-I\right) & =0 \\
\pi_{u}^{N}(r) & =0 .
\end{aligned}
$$

Proposition 2.1 Equilibrium Strategy The competition between the informed and the uninformed bank has a mixed-strategy equilibrium for defaulters. In this equilibrium,

1. $\varphi>\bar{\varphi}$ : the informed bank bids

$$
F_{i}^{G D}=1-\frac{N_{B D}\left(I-p_{B D} r\right)}{N_{G D}\left(p_{G D} r-I\right)}
$$

where $F_{i}^{G D}$ is defined on $\left[\bar{r}_{D}, R\right]$. It bids pure-strategy $r_{N}$ for the non-defaulting group and refrains from bidding for the bad-signal, defaulting group.

The uninformed bank bids

$$
F_{u}^{D}(r)=\varphi F_{i}^{G D}
$$

on $\left[\bar{r}_{D} ; R\right)$. It does not bid with probability $1-F_{u}^{D}(R)=\frac{p_{G D} \bar{r}_{D}-I}{p_{G D} R-I}$ and bids pure-strategy $r_{N}$ for the non-defaulting group.

$2 . \varphi>\bar{\varphi}$ : Both the informed and the uninformed bank always offer credit to all borrowers. The informed bank bids

$$
F_{i}^{G D}=1-\frac{N_{B D}\left(I-p_{B D} r\right)}{N_{G D}\left(p_{G D} r-I\right)}
$$

where $F_{i}^{G D}$ is defined on $\left[\bar{r}_{D}, \bar{r}_{B D}\right]$, and bids $\bar{r}_{B D}$ for the bad-signal, defaulting group. The uninformed bank bids

$$
F_{u}^{D}(r)=\varphi F_{i}^{G D},
$$

on $\left[\bar{r}_{D} ; \bar{r}_{B D}\right)$ with a point mass at $\bar{r}_{B D}$. Both banks bid pure-strategy $r_{N}$ for the non- 
defaulting group.

Proof See Appendix.

The interest rates are depicted in figure 3 .

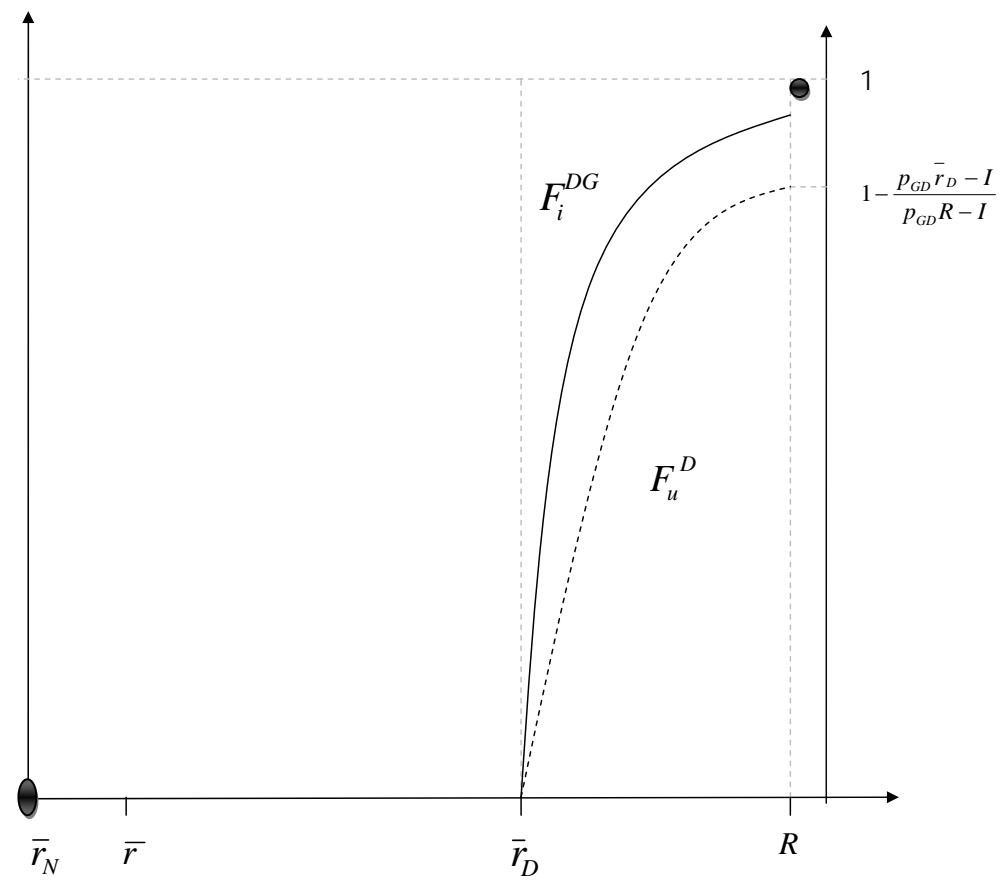

Figure 3: Interest rates under information sharing. Dashed line represent uninformed banks' bidding. both banks bid $r_{N}$ for non-defaulting borrowers.

The informed bank chooses different rates for the good- and bad-signal borrowers, while the uninformed bank is unable to make that distinction. Both banks can distinguish between defaulting and non-defaulting borrowers, so we can think of the competition between the two banks as taking place on two separate markets (for defaulting and non-defaulting borrowers respectively). The proposition has an intuitive property that will hold throughout the analysis: better types receive better loan terms (from the incumbent), where better is measured by a favorable hard or soft information. Indeed, the non-defaulters $N$ get as low as $\overline{r_{N}}$ : because the true type of successful borrowers is revealed to be high, banks compete purely a la Bertrand. At the same time, good signal defaulters get higher rates in $\left[\overline{r_{D}} ; R\right]\left(\left[\overline{r_{D}} ; \overline{r_{B} D}\right]\right.$ as in case 2), while bad signal ones are turned down (or receive highest rates $\overline{r_{B} D}$ ] in case 2 ).

The uninformed bank's bidding is intuitive, too: because it faces adverse selection from the borrower pool of the incumbent bank, its interest rate bids are not on average lower $(\varphi \leq 1)$. Finally, the uninformed bank may sometimes deny credit when informativeness of the monitoring is high enough. Thus, some of the $B D$ types, who can 
only resort to getting credit from the uninformed bank under high informativeness, may in fact be rightly denied access to credit at all. Comparison of the two regimes will reveal, that this is more pronounced under information sharing, and is a source of welfare improvement.

The incumbent bank will make positive profits on good-signal borrowers, and will not bid for bad-signal borrowers. Uninformed banks will make zero profits, but they will sometimes get the good-signal borrowers. ${ }^{11}$

Proposition 2.2 The expected gross profits for the incumbent bank when default information is shared is given by

$$
\pi_{\text {share }}=I(1-\lambda)(2 \varphi-1)
$$

The uninformed bank makes 0 profits.

Proof See Appendix.

The gross profits of the incumbent bank are increasing in the informativeness of the monitoring signal, as one would expect: the more intensive the monitoring, the higher are the appropriated monopolistic rents.

\subsection{No information is shared}

We describe now the case where there is no credit bureau in the economy. At the beginning of the second period, both default and monitoring information are known only to the incumbent bank. The second period timing is:

$T=2$

- Banks do not share hard information.

- Simultaneously the informed and the uninformed banks offer second period interest rates. Each bank has three types of borrower group from first period lending, and another group from the competitor bank.

- The firm chooses an offer and invests $I$. If indifferent, the firm chooses randomly.

- Profits are realized based on soft information and default information.

Similar to the case with information sharing, there is no pure strategy equilibrium, but there is a mixed-strategy one.

\footnotetext{
${ }^{11}$ Good borrower switching is a key property of the mixed-strategy equilibrium that stands in contrast with sequential move games, where all good borrowers are held up by the incumbent (see, for instance, Padilla and Pagano(2000)). This is in line with the vast recent evidence on borrower-bank relationships (see for example Ioannidou and Ongena 2008).
} 
Let $F_{u}(r)$ denote the bidding strategy of the uninformed bank. Given the firstperiod monitoring $\varphi$, the profit functions for the incumbent bank can be written as follows:

$$
\begin{aligned}
\pi_{i}^{N}(r) & =N_{N}\left(p_{N} r-I\right)\left(1-F_{u}(r)\right) \\
\pi_{i}^{G D}(r) & =N_{B N}\left(p_{B N} r-I\right)\left(1-F_{u}(r)\right) \\
\pi_{i}^{B D}(r) & =N_{B D}\left(p_{B D} r-I\right)\left(1-F_{u}(r)\right)
\end{aligned}
$$

The uninformed bank only has one bidding function since it cannot distinguish between any of the types in this case - not even between defaulting and non-defaulting borrowers.

The profit function for the uninformed bank is given as follows:

$\pi_{u}(r)=N_{N}\left(p_{N} r-I\right)\left(1-F_{i}^{N}(r)\right)+N_{G D}\left(p_{G D} r-I\right)\left(1-F_{i}^{G D}(r)\right)+N_{B D}\left(p_{B D} r-I\right)\left(1-F_{i}^{B D}(r)\right)$

The proportions of the types and their success probabilities are expressed in the same way as in the previous case. Before characterizing the equilibrium, we remind the definition of $\overline{r_{D}}$, the break-even interest rate for the two least qualified groups, the defaulting borrowers $G D$ and $B D$ (both good- and bad-signal).

Proposition 2.3 Equilibrium Strategy The competition between the informed and the uninformed bank has a mixed-strategy equilibrium for defaulters. In this equilibrium,

1. when $\varphi>\bar{\varphi}$, the informed bank

- bids only for non-defaulting borrowers in $\left[\bar{r}, \bar{r}_{D}\right]$;

$$
F_{i}^{N}=1-\frac{N_{B D}\left(I-p_{B D} r\right)+N_{G D}\left(I-p_{G D} r\right)}{N_{N}\left(p_{N} r-I\right)}=\frac{\lambda p r-I}{\lambda p(p r-I)}
$$

- bids only for good signal borrowers that have defaulted in $\left[\bar{r}_{D}, R\right]$;

$$
F_{i}^{G D}=1-\frac{N_{B D}\left(I-p_{B D} r\right)}{N_{G D}\left(p_{G D^{r}}-I\right)}
$$

with a point mass at $R$.

- refrain from bidding for the bad-signal, defaulting group.

The uninformed bank bids

$$
F_{u}(r)=1-\frac{p_{N} \bar{r}-I}{p_{N} r-I}=\frac{\lambda p r-I}{\lambda(p r-I)}=p F_{i}^{N}
$$


on $\left[\bar{r}, \bar{r}_{D}\right]$,

$$
F_{u}(r)=1-(1-p) \frac{p_{G D} \bar{r}_{D}-I}{p_{G D} r-I}=p+(1-p) \varphi F_{i}^{G D},
$$

on $\left[\overline{r_{D}} ; R\right)$. It does not bid with probability $1-F_{u}(R)=(1-p) \frac{p_{G D} \bar{r}_{D}-I}{p_{G D} R-I}$

2. when $\varphi \leq \bar{\varphi}$, all banks bid for all borrowers

Proof See Appendix.

The rates are depicted in figure 4. To save space, details on the case $\varphi \leq \bar{\varphi}$ are provided in the appendix. As under information sharing, the uninformed bank faces

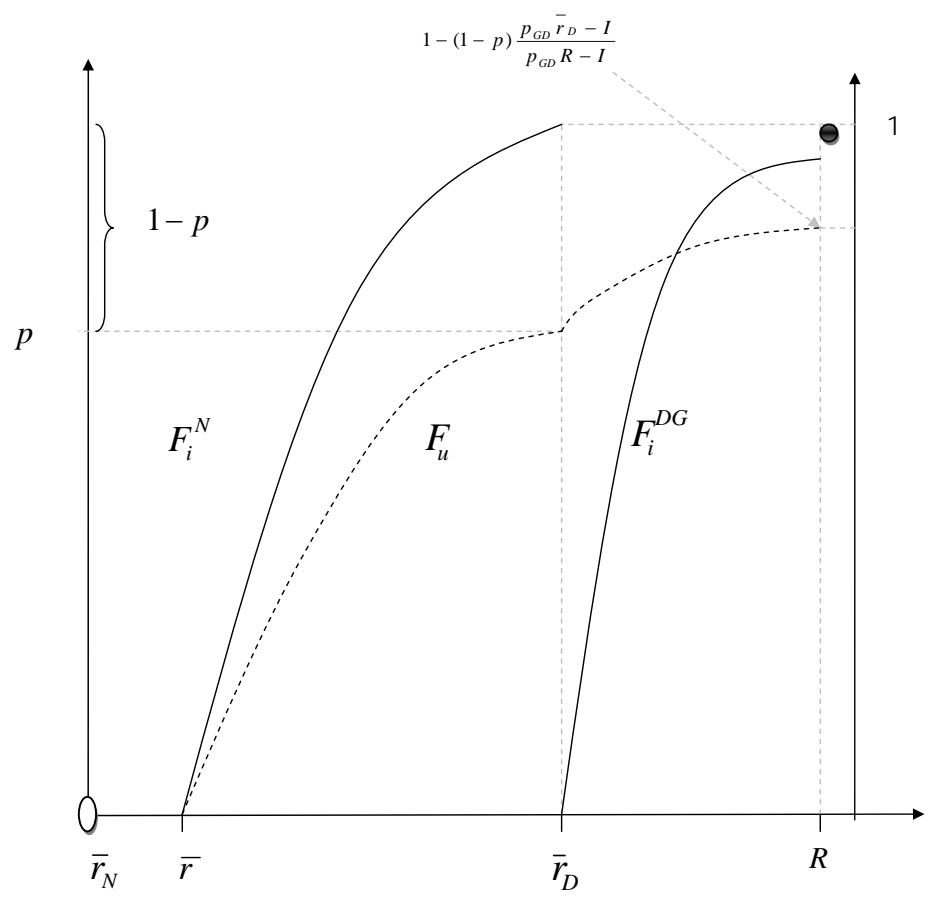

Figure 4: Interest rates under no information sharing. The dashed line represents uninformed banks' bidding

adverse selection and the offered rates are not lower: in this case, however it faces adverse selection from hard information as well. While success probability $p$ did not matter under information sharing, it does matter under no information sharing. Once again, better types receive better interest rates.

The term $1-p=\frac{p_{N} \bar{r}-I}{p_{N} \bar{r}_{D}-I}$ comes from the pooling of better population - the nondefaulters. Indeed, at $\bar{r}_{D}$, the uninformed bank already bids rather aggressively for the defaulting borrowers (with probability $p=1-\frac{p_{N} \bar{r}-I}{p_{N} \bar{r}_{D}-I}=F_{u}\left(r_{D}\right)$ it bids lower than that) compared to the information sharing case. Because, contrary to the case with 
information sharing, the uninformed bank confuses best types with defaulting borrowers, it is willingly more aggressive with them. Finally, as under information sharing regime, the uninformed bank may sometimes deny credit when informativeness of the monitoring is high enough. From equilibria under both regimes (propositions2.3 and 2.1), we will see that uninformed bank makes less type II mistakes under information sharing. We will come back to this point under welfare discussion.

\subsection{Information Rents and Optimal Monitoring}

Proposition 2.4 Informational rents are given by:

For the informed bank under information sharing

$$
\pi_{\text {share }}=I(1-\lambda)(2 \varphi-1)
$$

For the informed bank, under no sharing

$$
\pi_{\text {noshare }}=I p(1-\lambda)+I(1-p)(1-\lambda)(2 \varphi-1)
$$

Under both regimes, informational rents are growing in the informativeness of the monitoring. This proposition therefore provides a theoretical counterpart to the empirical findings that bank rents grow with relationship intensity (Degryse and Cayseele 2000, Ioannidou and Ongena 2009).

We can now compare the optimal choices of monitoring with and without information sharing.

Proposition 2.5 Marginal return to soft information is higher under hard information sharing:

$$
\frac{\partial \pi_{\text {share }}(\varphi)}{\partial \varphi} \geq \frac{\partial \pi_{\text {noshare }}(\varphi)}{\partial \varphi}
$$

Optimal investment in monitoring is higher under information sharing, and is given by:

$$
\begin{gathered}
\varphi_{\text {share }}=0.5+\frac{I}{c}(1-\lambda) \\
\varphi_{\text {noshare }}=0.5+\frac{I}{c}(1-\lambda)(1-p)
\end{gathered}
$$

Proof See Appendix.

Because under no information sharing the informed bank is likely to lose some of its $G D$ borrowers to the uninformed bank, it is less motivated to invest in monitor- 
ing. The payoff to the monitoring is lower by fraction $1-p$ : the uninformed bank is rather aggressive towards defaulting borrowers when information is not shared (it bids (weakly) lower than $\bar{r}_{D}$ for $D$ borrowers and wins them almost surely, and higher than -with only $1-p$ ). It does so because it cannot distinguish between the defaulting and non-defaulting groups. However, the uninformed bank is less aggressive under information sharing (bids higher than $\bar{r}_{D}$ for $D$ borrowers with certainty), leaving them to the incumbent more often. Using firm level data, we test and confirm that firms that operate in countries where information sharing is established, invest more in their borrowers, using several proxies of soft information investment.

Proposition 2.6 Optimal investment in soft information is increasing in the risk parameters in the economy $1-\lambda$, and $1-p$.

Proof Obvious and omitted.

Relying on the arguments that small firms are a much more opaque and risky population (see Berger et al 2005, among others), we test whether our findings are more pronounced for small firms.

Proposition 2.7 If monitoring costs are low enough $(c<2 I(1-\lambda)(2-p))$, secondperiod informational rents will be higher under information sharing.

Proof Indeed, plugging in optimal values, one can see that $\pi_{\text {share }}^{\text {optimal }}=\frac{2 I^{2}}{c}(1-\lambda)^{2}>$ $I p(1-\lambda)+\frac{2 I^{2}}{c}(1-\lambda)^{2}(1-p)^{2}=\pi_{\text {noshare }}^{\text {optimal }}$ will yield the necessary condition.

Thus, second period informational rents can be higher under information sharing, unless the increased cost from higher monitoring outweighs benefits from the higher return. Therefore, once banks start their competition when they already their own borrower's previous history, our model shows how this can lead to endogenizing the information sharing mechanism (see Jappelli and Pagano (1993) and Padilla and Pagano (1997) for similar setups).

\subsubsection{First Period}

At the beginning of first period banks compete for the whole population, under symmetric information: banks know the proportion of the good and bad borrowers and their success probabilities. The total profits across two periods are given by

$$
\lambda\left(p R_{1}-I\right)+\beta \pi^{\text {sharing }}
$$

and

$$
\lambda\left(p R_{1}-I\right)+\beta \pi^{\text {nosharing }}
$$


under information sharing and the no sharing regimes, respectively. Under both regimes banks start with symmetric information at the beginning of period 1. Banks compete in period 1 for 2 nd period captive markets, and this will drive the total profits across the two periods to 0, like in Padilla and Pagano (2000).

However, the fact that first period competition drives down banks' informational rents in period two yielding o profits in total, does not render information sharing an institution of irrelevance from bank's point of view. If banks do not anticipate the establishment of credit bureau, and decide to share information based on already existing borrower markets, our equilibria analysis of the two regimes in period 2 shows how information sharing may arise endogenously, increasing banks' rents. These setups are Jappelli and Pagano (1993) and Padilla and Pagano (1997), where banks decide on information sharing in 1-period games, by already having established markets and borrower history rather than, competing for them in an initial period.

\subsection{Interest Rates and Switching}

Proposition $2.8 F_{i}(r)$ and $F_{u}(r)$ for all groups of borrowers, as well as the minimum of the two rates for each borrower, are non-increasing in $\varphi$ under both information sharing and no information sharing regimes.

Proof See Appendix

Proposition 2.9 Expected interest rates paid by borrowers, are non-decreasing in informativeness $\varphi$ under both regimes.

Proof See Appendix

As investment in soft information increases, it also raises interest rates that borrowers pay. Rather than leveling the playing field, superior knowledge about borrowers provides the incumbent with stronger safeguard from competition, due to a higher asymmetric information. Because the uninformed bank faces larger winners' curse, it bids less aggressively in equilibrium. The response by the informed bank is to bid less aggressively as well, leading to higher expected interest rates. This complements to the recent findings that utilize detailed data from U.S. (Schenone (2009)) and Bolivia (Ioannidou and Ongena (2009)).

Proposition 2.10 Redistribution:

H(1). Bad signal borrowers get weakly higher rates than good signal borrowers under both regimes,

H(2). Non-defaulting borrowers get weakly lower rates under information sharing than no sharing,

H(3). Defaulting borrowers get weakly higher rates under information sharing, H(4). Overall, borrowers are on average weakly better-off. 


\section{Proof See Appendix}

Thus, the assertion that information sharing will unilaterally decrease interest rates may be premature. Previous work in this are has shown that information sharing decreases interest rates (Brown et al 2007, Jappeli and Pagano 2002). Due to lack of data, empirical evidence has failed to take into account how borrower default affects interest rates. A testable implication remains for future research: borrowers with default will receive higher rates, and borrowers with no-default receive lower rates on average. However, the findings that overall borrowers are better off is consistent with existing literature and with our evidence. This is because the uninformed bank faces a higher winner's curse, due to a more precise evaluation of borrowers by the informed bank. It bids less frequently for the (worse) switching borrowers, and avoids making too many type II mistakes. This saving is a transfer to the creditworthy borrowers because banks compete any lifetime profits in period one.

Proposition 2.11 Switching probabilities are given by

\begin{tabular}{|l|l|l|}
\hline & Sharing & No Sharing \\
\hline \hline Group $N$ & $\frac{1}{2}$ & $\frac{1}{2} p$ \\
Group GD & $\frac{1}{2} \varphi_{\text {share }}$ & $p+\frac{1}{2}(1-p) \varphi_{\text {noshare }}$ \\
Group $B D$ & $\varphi>\bar{\varphi}, 1$ & $\varphi>\bar{\varphi}, 1$ \\
& $\varphi \leq \bar{\varphi}, \frac{1}{2}\left(1-\varphi_{\text {share }}\right)+\varphi_{\text {share }}$ & $\varphi \leq \bar{\varphi}, p+\frac{1}{2}(1-p)\left(1+\varphi_{\text {noshare }}\right)$ \\
\hline
\end{tabular}

Thus,

H(1). Bad signal borrowers switch more than good signal ones under both regimes, H(2). Defaulting borrowers may overall switch more or less, H(3). Non-defaulting borrowers switch more under information sharing, $H(4)$. Change in overall switching across regimes is inconclusive.

\section{Proof See Appendix}

We can see that non-defaulting borrowers are more likely to switch under information sharing, when their success story becomes public. Our results show that defaulting borrowers may or may not switch more under information sharing depending on whether borrower heterogeneity is more important ( $p$ is high) or the informativeness of the signal. In the former case, because defaulting borrowers get pooled with much better borrowers, they will tend to switch more often when that heterogeneity is not yet revealed to the uninformed bank.

In the latter, however, if the good signal has high enough informativeness under information sharing $\left(\varphi_{\text {share }}\right.$ is large enough), borrowers may in fact switch more since informed banks try to squeeze too much, compared to the uninformed banks: remember that $F_{u}^{D}(r)=\varphi F_{i}^{G D}$ and optimal informativeness is higher under information 
sharing. ${ }^{12}$. As a result of these, information sharing may not necessarily facilitate switching overall, despite leveling the playing field between banks. The interest rate strategies and the resulting switching mechanics described above are not as simple as in the case of a hypothetical pure-strategy equilibrium in which borrowers never switch to less-informed banks. However, the model intuition and its implications are arguably realistic. We test that higher investment in soft information is related to more switching. Ioannidou and Ongena (2009) present compelling empirical evidence that is consistent with the idea of incumbents accumulating informational rents and borrowers occasionally switching banks as a result of excessive interest rates. Ongena and Smith (2001) and Farinha and Santos (2002) provide evidence that the likelihood a firm switches the lender increases in relationship intensity. In our proposition too, switching increases weakly in informativeness, except in the case for hard borrowers, for whom relationship does not matter.

\subsection{Welfare Implications}

We now address the important question of how socially desirable information sharing is in our model. When informativeness of the acquired information is high enough $(\varphi>\bar{\varphi})$, banks can add to the social value of the information production by rejecting credit to uncreditworthy borrowers (fewer type II mistakes). The higher informativeness under information sharing allows banks to evaluate their borrower's true types more precisely, and reject more low quality borrowers. when these borrowers switch to the uninformed bank, the latter realizes that it faces a higher winner's curse, and in turn rejects credit more often, thus making fewer type II mistakes under information sharing. Such an outcome is a transfer to the creditworthy borrowers, since banks' total lifetime profits remain unchanged. Information sharing may thus increase welfare, unless monitoring costs are too high.

Formally, welfare consists of the sum of all NPV projects, plus the savings that the uninformed bank makes by not extending credit to the uncreditworthy, less the mistakes it makes by not doing so, less costs of monitoring.

$$
W=\lambda(p R-I)-(1-\lambda) I+((1-\lambda) \varphi-\lambda(1-p)(1-\varphi))\left(1-F_{u}(r)\right)-c(\varphi-05)^{2}
$$

$c \leq \frac{0.5(1-\lambda)(1-p)-p \lambda}{R / I+(1-p)(1 / \lambda)}$, the benefits from fewer bad loans exceed costs of higher monitoring under information sharing. ${ }^{13}$ Thus, although information sharing induces defaulting borrowers to pay higher rates, and non-defaulting borrowers lower rates, overall creditworthy borrowers gain, since banks make less type II mistakes.

\footnotetext{
${ }^{12}$ Contrast this to the uninformed bank's less sensitive bidding under no information sharing $\left(F_{u}(r)=\right.$ $\left.p+(1-p) \varphi F_{i}^{G D}\right)$ and lower $\varphi$

${ }^{13}$ Alternatively, one could include the monitor as one of the agents that the social planner cares about, and monitoring costs - as a transfer to/profit for the monitor. In that case welfare increases unambiguously.
} 


\section{Empirical Evidence}

To the best of our knowledge, there has been no study on the impact of hard information sharing on soft information acquisition. This section attempts to fill this gap, and corroborate theoretical findings above. Our main hypothesis is that soft information acquisition increases when hard information is shared. We then test that good soft information outcomes reduce interest rates and switching, while bad outcomes increase both. Earlier empirical studies have instead focused on the influence of information sharing on credit market performance, or firms' access to credit. Jappelli and Pagano (2002) use aggregate data to show bank lending to the private sector is larger and default rates are lower in countries where information sharing is more solidly established and extensive, controlling for other economic and institutional determinants of bank lending, such as country size, GDP, growth rate, and variables capturing respect for the law and protection of creditor rights. Djankov et al. (2007) confirm that private sector credit relative to GDP is positively correlated with information sharing in their recent study of credit market performance and institutional arrangements in 129 countries for the period 1978 to 2003.

Throughout our analysis we study our hypotheses separately by distinguishing large and small firms. In our model we derive the prediction that soft information acquisition increases when hard information is shared. There are several reasons why one may expect that introducing hard information sharing may have a larger impact on small firms, than on large ones. First, credit information sharing arrangements target mainly the small business and consumer markets (unlike credit rating agencies, that usually deal with large firms). Second, since large firms already have available information, produced by their more developed internal and external reporting, sharing information via credit bureaus should have a lower impact for these firms. Part of what is available in a standard credit bureau report may already be available without a credit bureau for a large firm - e.g., information on company profile, audited financial statements, risk class of the borrower. Earlier research has shown that information can be particularly important for small firms since they are unlikely to be monitored by rating agencies, and information asymmetries are most acute in small firms (see, for example Petersen and Rajan (1994)). Thus, apart from testing that hard information sharing increases soft information acquisition, and that the switching is changed as a result of soft information outcome, we test whether these are stronger for small firms.

\subsection{Data}

We draw our data from two main sources. Country level data on information sharing is taken from the World Bank/IFC "Doing Business database. We relate this to firm-level information taken from the EBRD/World Bank Business Environment and Enterprise Performance Survey (BEEPS).

Between 1991 and 2005 information sharing institutions were established in 17 of 
the 26 transition countries in Eastern Europe and the former Soviet Union. ${ }^{14}$ The main sources of these data are the "Doing Business surveys, conducted by the World Bank/IFC (World Bank, 2006).

We use the information sharing index constructed by Brown et al (2007) as the measure of the depth of information sharing in different countries. The index measures the presence and structure of public credit registries and private credit bureaus on a scale of 1 to 5. It is constructed as the maximum of two scores, one for PCRs and one for PCBs. The PCR score adds one point for fulfilling each of the following five criteria:

(i) both firms and individuals are covered,

(ii) positive and negative data is collected and distributed,

(iii) the registry distributes data which is at least two years old,

(iv) the threshold for included loans is below per capita GDP, and

(v) the registry has existed for more than 3 years.

The PCB score is computed in the same way. The index is then taken as an average over years 1996 to 1999 for the analysis of year 2002, and average over 2000-2003 for year 2005.

Detailed definitions of all variables are available in the Appendix B. The BEEPS 2002 provides data on 6153 firms in 26 transition countries and covers a representative sample of firms for each of these countries (survey was done in all countries where EBRD is operational except in Tajikistan), while BEEPS 2005 covers over 9655 firms. As in Brown et al, we drop all observations from Uzbekistan and Tajikistan, due to lack of institutional indicators for these countries. Together with missing dependent variables, this leaves us with a sample of 5209 firms at best from 24 countries for year 2002 and with 8599 for year 2005.

\subsection{Dependent Variables}

We relate our information sharing index to firm-level data on our independent variables taken from the Business Environment and Enterprise Performance Survey (BEEPS)(see Table 1).

We use 1) three dependent variables to measure the investment in proprietary information, 2) a dummy showing whether the borrower switched from the main bank, and 3) cost of capital:

1. borrower switching/keeping relationship with the main bank; switch

2. the banks' reaction to the borrower's non-repayment during the relationship (the reaction as perceived by the borrowers); react

3. the days needed to approve the loan starting from the date of application; days

4. the use of checking account; checking account

\footnotetext{
${ }^{14}$ For a comprehensive coverage see Table 1 in Brown et al 2007
} 
5. the cost of capital.

Our cross-sectional analysis is based on data from BEEPS 2002 for three variables (switch, days, react), BEEPS 2005 is used for checking account and capital cost is available in 2002 and 2005. The last variable allows us to build a panel regression, which is based on responses of 1333 firms who participated in both the 2002 and 2005 surveys.

\subsection{Model Specifications}

We start our empirical analysis with cross-sectional regressions using the BEEPS 2002. The baseline specification relates each of our five dependent variables for firm $\mathrm{i}$ in country $\mathrm{j}$ to the information sharing index in the firms country, a vector of other country characteristics, and a vector of firm characteristics.

Our dependent variables were collected during 2002, while information sharing is measured as the average value of the index prior to the survey, i.e. from 1996 to 1999 for 2002, and 2001-2003. Thus, we relate firm-level information to countrywide measures of information sharing that are predetermined with respect to credit variables and this should address the potential endogeneity of information sharing with respect to credit market performance (see also Brown et al 2007).

We will test our theory using 5 dependent variables. Specifically, we test three hypotheses

1) whether soft information acquisition (that is, informativeness $\varphi$ ) has increased using three proxies of $\varphi\left(i_{j}\right)$ for firm $i_{j}$ (dependent variables days, react, checking account)

$$
\varphi\left(i_{j}\right)=\alpha+\gamma \times \text { contorls }_{\text {firm }(i(j))}+\delta \times \text { controls }_{\text {country }(j)}
$$

2) how switching has changed depending on the signal sign of the informativeness $\varphi$ - good or bad, using a measure of whether the soft information has been good or bad (variable soft)

Switching $_{i_{j}}=\alpha+\beta \times \operatorname{softsignal}(G / B)+\gamma \times$ contorls $_{f i r m(i(j))}+\delta \times \operatorname{controls}_{\text {country }(j)}$

This is proposition $2.11 \mathrm{H}(1)$ showing that switching and interest rates depend on the outcome of the signal: good or bad

3) And similarly, cost of capital changes depending on the soft signal following from 2.3 and 2.3 .

Cost.firm $\left(i_{j}\right)=\alpha+\beta \times \operatorname{softsignal}(G / B)+\gamma \times$ contorls $_{\text {firm }(i(j))}+\delta \times$ controls $_{\text {country }(j)}$ 


\subsubsection{Country level variables}

We include eight country-level variables to control for differences in the legal environment, the structure of the banking sector, and macroeconomic performance (Table 2 provides means of the variables): an index of creditor rights, banking reform, a measure of market structure/concentration, a proxy for asymmetric information and borrower risk, a measure of foreign bank presence, per capita GDP,credit to private sector/GDP and the inflation rate. The banking concentration measure is the share of the largest 5 banks in terms of deposits (from Barth et al 2001): higher concentration may indicate higher market power of the banks, higher informational lock in, and therefore less switching. Moreover, since larger banks are less efficient in collecting soft information (Berger et al 2005), higher concentration may have a negative impact on the information acquisition. Also, in more competitive markets, banks anticipate a shorter expected lifespan of their relationships, and they may respond by reducing their relationship-specific investments. Weaker relationships may then induce switching further. We take the share of non performing loans as a measure of asymmetric information. In markets with higher degree of risk, switching will be more costly: we expect a negative sign on this variable for switching. The Creditor rights variable is taken from Brown et al (2007). Higher values of this index imply that secured lenders are better protected in case a borrower defaults.

The banking reform index is an index showing level of changes from a state owned bank with soft-budget constraints to a commercial bank with hard budget constraints in a market economy. Foreign bank share variable is the asset share of foreign owned banks in each country. Recent evidence suggests that foreign bank entry has improved credit market performance in transition countries (Giannetti and Ongena 2005). Also, foreign bank presence may coincide with information sharing, if these banks are familiar with the benefits of credit reports from their home markets, and therefore tend to patronize private credit bureaus also in their host countries. Alternatively, when foreign banks are serving foreign firms in the host country, they might be able to access their information through their home bureaus, and are less interested in information sharing. We include inflation and log of per capita GDP, as previous evidence suggests that macroeconomic stabilization is associated with an expansion in financial intermediation in transition countries (Fries and Taci, 2002).

\subsubsection{Firm level explanatory variables}

All firm level explanatory variables are detailed in the Appendix for variables. We include six firm-level explanatory variables to control for the variation in credit risk and financing requirements across firms, and we use two different measures of good/bad soft information.

Younger firms are generally considered as more risky than older firms. However, 
in transition countries firm age also determines the economic regime under which the firm emerged. Thus, while older firms may be less risky in general, they may be riskier in transition countries, because they emerged during the pre-transition or transition phase. Rather than controlling simply for firm age, we therefore distinguish firms by three categories depending on whether they were established before 1989 (Pretransition firm), between 1989 and 1993 (Transition firm), after 1993 (Post-transition firm) (Brown et al 2007, Gianetti and Ongena 2005). We further include two control variables for firm ownership. State-owned firm is a dummy variable that equals one if the government holds a majority stake in the firm. The effect of this variable is a priori ambiguous. On the one hand, state ownership may reduce firm risk in the eye of a bank, due to the possible government bailout in case of default. On the other, state ownership may increase default risk, owing to the political pressures on management to diverge from profit-maximizing policies (see Brown et al 2007). Moreover, these firms may receive public funding, which reduces their reliance on credit for investment and therefore relieves a constraint on their growth.

As discussed above, we are also interested in the differential effect depending on the firm size. Moreover, it is customary to regard larger firms as less risky, other things equal. We distinguish small firms from large ones by their number of employees (Small firm $=1-49$, Large firm $\geq 50$ ).

From BEEPS survey 2002 and 2005, we construct the summary variable soft signal (1), that measures how protected the borrower is from different non-financial factors. It summarizes answers to 19 questions on "non financial problems of growth". The exact question in the survey asks: Can you tell me how problematic are these factors for the operation and growth of your business?. The factors include skills of workers, their education, contract violations by customers and suppliers, among others. Arguably, relationship-specific investment is necessary to evaluate how problematic these factors are for the operations and growth of the firm. We rescale the summary variable to range from [0.21to1], with lower value indicating problems (=the bank receives bad $\operatorname{signal}(B)$, when monitors on these issues. As a further measure of the sign of the soft information, we use management quality (soft signal (2)), which is considered as one of the most important soft characteristics of the firm (Grunert, Norden, Weber (2005)). In our sample it is the sum of three variables: previous experience of the manager within that firm, the age of the manager, the manager's education. Each of the variables takes several values in the survey. The variable ranges from 0 to 3 , and higher values of the management quality would mean better signals for the lender. Finally, in all our regressions we include sector dummies, to control for different finance needs of firms. ${ }^{15}$

The data provides a similar sample of non-agricultural firms across all countries. The sample is dominated by small firms $(67 \%)$ and private firms $(86 \%)$. The sam-

\footnotetext{
${ }^{15}$ Although some of these variables can be regarded as pieces of hard information, we believe the general picture may have a proprietary nature for the main bank.
} 
ple includes firms from service and manufacturing sectors, with the majority of firms $(54 \%)$ have their main activity in the service sector. All firms in the sample are at least 3 years old. The 2005 survey includes 9655 firms. The sample structure for the 2005 survey resembles by design that of the 2002 survey.

\subsection{Regressions}

\subsubsection{Soft Information Acquisition}

Our aim is to provide empirical evidence that in support of the theory: banks invest more in soft information once hard information is shared. In order to examine this hypothesis, which is also the main message of our paper, we look at several aspects:

- the days banks spend to approve a loan application;

- how flexibly banks react to late payments from their borrowers;

- the use of checking account as a way to accumulate information on borrowers.

\section{Days}

The days variable is taken from the BEEPS 2002 survey. The question in the survey asks, "How many days did it take to agree the loan with the bank from the date of application?" The mean is 25 , with standard deviation 37 . The dependent variables is the reported days. ${ }^{16}$ The reported output in table 3.4.3 is based on robust OLS estimation. Due to the existence of some outliers in the dependent variable days, we also estimated $\log$ of days, not presented here for brevity. This yields identical qualitative results to those presented in column (1) of Table 5. The significance is preserved also when Poisson estimation used. In all specifications, the standard errors of the estimated coefficients are adjusted for cluster effects at the country level. The first column is the estimate for the total sample, the second one is only for small firms, while the third one is for large firms.

Investment in soft information by screening a loan application requires time. A bank that carefully screens its borrowers will have to spend more time before making the loan decision. If the information the bank relies on is hard, then the time interval will arguably be lower, since the borrowers have to prepare in advance the standardized information needed to get a loan. Finally, if the bank does little screening of either type, then the basic standardized procedures in that case will likely take very little time, too. ${ }^{17}$

The first column shows that information sharing is related with more time to conclude the loan application. Column 2 shows that the effect is largely driven by small

\footnotetext{
${ }^{16}$ The existence of the many outliers motivates our use of the logarithm

${ }^{17}$ It should be reminded here that we solve our model for ex-ante screening of borrowers by banks. Our theoretical results are reminiscent to the monitoring case analyzed in the paper. In particular, investment in screening efforts is higher under information sharing.
} 
firms, while column 3 is for large firms, confirming our prediction from 2.6. We also use Poisson regressions, where our results are similar, and we have $1 \%$ significance on information variable. The magnitude is economically quite large. The first coefficient on information index shows that moving from lowest to highest value of information sharing (from 0 to 4.6) may increase days for application processing as much as 16 days, rather large for the sample average of 25 .

Importantly, a bank may also spend more time before making the loan simply because its procedures are inefficient. This is a reasonable worry in our case, since banking systems have been undergoing radical changes during the last two decades, and their efficiency has been transformed. Therefore the days variable can differ largely owing to the strength of legal and institutional reforms. We control for this through the variables Banking reform index, collateral law development, and creditor rights. Higher values of these indices reflect reforms that encourage financial discipline and governance and enforce the law. The negative coefficients on these controls point to the less time needed when financial discipline is stronger.

Concentration has a negative impact, since higher concentration means larger banks may use more hard information and standardized procedures, giving small role to screening and approving loans faster. As expected, stronger creditor protection allows to approve loans faster, since creditors worry less about defaults. For post transition younger firms banks may be using more impersonal and modern communication, in line with earlier findings that older firms are closer to their banks and are less likely to have impersonal communication. Indeed, apart from age, this is even more plausible for a pre-transition vs. post-transition borrowers. There may also be a role for the vintage effect (Berger et al 2005); older borrowers started their careers with their bankers face-to-face and have not changed their ways of communicating with their banks.

\section{Banks' reaction}

The reaction variable is taken from the BEEPS 2002 survey. The question in the survey asks: "Now I would like to ask you a hypothetical question. If your firm were to fall behind in its bank repayments, which of the following would best describe how you would expect the bank to react?" Higher values indicate lenient reaction by the bank, with possible answers; 1 . Extend the term of the loan without changing the conditions $(=3), 2$. Extend the term of the loan but increase the interest rate $(=2)$, or 3. Begin legal proceedings to take possession of some assets of the firm $(=1)$.

Arguably, if the bank reacts more flexibly in case of late payments (higher values of the variable), it must be that the bank has a good knowledge and is optimistic of the firm. In that case the bank relates late payments to bad luck, rather than to gloomy prospects. In contrast, a bank that does not invest in monitoring or screening its borrowers will simply take late payments as a pure negative signal about the firm's 
potential and will be more likely to cease the banking relationship. ${ }^{18} 2000$ firms reply to this question. The output in table 3.4.3 is ordered probit, although robust OLS estimates have similar economic magnitude, and are statistically signifcant at $5 \%$. In all specifications, the standard errors of the estimated coefficients are adjusted for cluster effects at the country level.

The table shows have high significance for the information sharing index, both for the whole and the small firm samples. Calculation of marginal effects shows that moving from smallest to highest information index can change reaction of the bank by 0.45 (mean 2.26). Our conjecture on the firm size effect explains the no-significance of the large firm subsample.

Intuitively, bank reform index has a negative sign: banks with binding hard-budget constraints will be stricter to their borrowers. The regression shows that younger, post transition firms seem to enjoy less leniency from their banks when they fall behind payments: again, we explain this by the fact information acquisition via monitoring may take a long-standing relationship.

\section{Checking account}

The checking account variable is taken from the BEEPS 2005 survey. The question in the survey asks: "Does your establishment have a checking or saving account". It has been observed that the use of checking account gives the bank advantageous information on the borrower, works as a monitoring tool for the lender and is used in the borrower's "internal rating" (Puri et al (2009), Degryse and van Cayseele (2000), Norden and Weber (2008), Nakamura (1991)). Moreover, evidence suggests that there is a positive impact of the checking account existence on the probability of personal communication between the bank and the borrower (Berger et al 2005). Table 3.4.3 shows that checking account is used more in countries with information sharing, supporting our hypothesis on more investment in monitoring in these countries.

Once again, columns 1, 2 and 3 are for overall, small and large firms, respectively. The coefficients show that there is higher likelihood a firm has a checking account, if it operates under information sharing: that is, $48 \%$ when moving from smallest to the highest information index. We do not find evidence in favor of larger importance for small firms for this variable, which we attribute to the fact that small borrowers are less likely to have checking accounts for many other reasons. ${ }^{19}$ In all three cases information sharing makes the use of checking accounts more likely. Concentration has a significant negative impact, in line with earlier arguments.

\footnotetext{
${ }^{18}$ Similar questions have been used as proxies of soft information on earlier studies, that utilize companies' grading of their main banks in terms of satisfaction (Ogura and Uchida (2006), Uchida, Udell and Yamori (2007)).

${ }^{19}$ Indeed many small firms may find it costly to open checking accounts in transition economies, or may borrow simply on personal accounts. See also Hogarth, Anguelov and Jinkook (2004), who find that households are generally less likely to have checking accounts, which is related to income, planning horizon, education and credit history.
} 


\subsubsection{Switching or Staying with the Main Bank?}

The switching variable is taken from the BEEPS 2002 survey. The question in the survey asks, Has your firm changed its main bank (the single bank with which your firm has the closest relationship) since 1998?'. Possible answers include "yes", "no", "no main bank". $8 \%$ of the firms report that they have no main bank, and we exclude those firms. This leaves us with a sample of 5209 firms). $26 \%$ of the firms report that they have switched their main bank. We also use the average information sharing index for year 1996-1998, to estimate switching after establishing information sharing. We would like to test whether signal of soft information is important for switching (proposition 2.11, $\mathrm{H}(1)$ ).

Table 3.4.3 is based on probit estimations and standard errors are adjusted for cluster effects at the country level. Explanatory variable soft signal (1) is a summary measure that proxies the sign of soft information acquired for the firm and shows how protected the firm is from each of the 19 non-financial problems discussed: range $[0.21 ; 1]$. Soft signal 2 is a proxy of management quality (1-3). Column 1, 2, 3 are run for overall, small and large firms, respectively. Columns 4, 5, 6 repeat the analysis adding soft signal (2). The first and second line strongly support 2.11, H(1). Calculating marginal effects, we find that this may generate up to $16 \%$ difference in switching, which is rather large given the $26 \%$ sample average. Furthermore, the insignificant information coefficients are justified by proposition $2.11, \mathrm{H}(4)$ - no expected difference in overall switching across regimes. We are not able to test the rest of hypotheses generated in the proposition 2.11 due to lack of data on borrower default.

\subsubsection{Cost of capital}

We begin analyzing the effects of information on cost of capital. It ranges from 1 to 4 , with higher values indicating a higher cost of financing. It equals 4 , if cost of finance is reported to be a major obstacle, $3=$ moderate obstacle, $2=$ minor obstacle, $1=$ no obstacle. Existing evidence suggests that information sharing benefits firms, in line with 2.10, H(3) (see Love and Mylenko 2003, Brown et al 2007). In this regression is to add to this study by looking at whether credit cost changes depending on soft information outcome, and whether this is stronger for small firms. Unlike Brown et al (2007), we also take into account soft information signal -good or bad, which generates important difference from what is reported in Brown et al (2007).

Table 3.4.3 is ordered probit output. Standard errors are adjusted for cluster effects at the country level. Robust OLS estimates give similar results. The table shows that higher values of soft signal (that is, good signals) reduce cost of capital, a little more so for small firms. This confirms our hypothesis - cost of capital is lower for good signal borrowers under both regimes (from proposition 2.3 and 2.1). Brown et al (2007) find 
that cost of capital is lower in countries with information sharing, and that this effect is larger for small firms (line 2 in the table, and 2.10, $\mathrm{H}(3)$.). Along with confirming this, we find that good soft signals reduce cost of capital too, and even more so than information sharing.

Higher concentration and stronger creditor rights seem to reduce cost of capital as well. We did not have any a priori prediction as to the sign post-transition and transition variables, since these are younger firms but, as argued before, may be less risky on the other hand, than pre-transition firms.

Table 3.4.3 repeats this analysis using panel estimates from 2002 and 2005. Our firm level variable do not change over time. First column is fixed effect estimation and second column is random effect estimation for the whole sample. Column 3 and 4 repeat fixed effects analysis for small and large firms, respectively. 


\section{Appendix A}

Proof of Proposition.2.1 Define the success probabilities

$$
\begin{aligned}
p_{N} & =p \\
p_{G D} & =\frac{\lambda \varphi p(1-p)}{\lambda \varphi(1-p)+(1-\lambda)(1-\varphi)} ; \\
p_{B D} & =\frac{\lambda(1-\varphi) p(1-p)}{\lambda(1-\varphi)(1-p)+(1-\lambda) \varphi}
\end{aligned}
$$

and the respective break-even rates $\bar{r}_{K}=\frac{I}{p_{K}}$, for $K=D, N, G D$ or $B D$.

The construction of the mixing strategies is done in a sequence of standard arguments outlined here, similar to Hauswald and Marquez (2006). For details, see Hauswald and Marquez (2000) or von Thadden (2004). Let $F_{u}^{K}(r)$ the uninformed bank's bidding distribution over loan-rate offers $r$, for defaulting $(K=D)$ and nondefaulting $(K=N)$ groups. $F_{i}^{J}(r)$ describes the bidding strategies for the informed bank for the good-signal defaulting $(J=G D)$, bad-signal defaulting $(J=B D)$ and the non-defaulting $(J=N)$ borrowers. Finally, let $t_{i}(J)$ and $r_{u}(K)$ denote interest-rate offers by the informed and the uninformed banks.

1. The non-defaulting borrowers: both banks know their repayment history, and compete a la Bertrand under symmetric information, offering marginal cost pricing $\bar{r}_{N}$.

2. Defaulting borrowers $(G D, B D, D)$ : Let $\bar{\varphi}$ denote informativeness level that solves $p_{B D}(\varphi) R=I$.

a) Suppose first $\varphi>\bar{\varphi}$.

The informed bank will not bid for $J=B D$, since they are not creditworthy (this is because $\left.\frac{\partial \bar{p}_{B D}}{\partial \varphi}=\frac{(1-2 \varphi) \lambda(1-\lambda) p(1-p)}{(\lambda(1-\varphi)(1-p)+(1-\lambda) \varphi)^{2}} \leq 0\right)$. Thus, $F_{i}^{B D}(r)=0$ for all $r$. Furthermore, it can be shown that $F_{i}(r)$ and $F_{u}(r)$ are continuous, strictly increasing, and atomless on some common support $[\underline{r}, \bar{R}$ ) (see von Thadden 2004). For $J=G D$, the informed bank gets expected profits for any $r$

$$
\begin{gathered}
\pi_{i, \text { share }}^{G D}(r)=N_{G D}\left(p_{G D} r-I\right)\left(1-F_{u}^{D}(r)\right) \\
\pi_{u, \text { share }}^{D}(r)=N_{G D}\left(p_{G D} r-I\right)\left(1-F_{i}^{G} D(r)\right)+N_{B D}\left(p_{B D} r-I\right)\left(1-F_{i}^{B D}(r)\right)
\end{gathered}
$$

Finally, it can be shown that the uninformed bank has to break even in the equilibrium, implying that $\pi_{u \text {,share }}(r)=0$ (von Thadden 2004). To calculate the lower bound of the common support, observe that the uninformed bank wins the defaulter almost surely at that rate and gets $\underline{r} p_{D}-I$, implying $\underline{r}=\bar{r}_{D}$. For the upper note that none of the banks will clearly bid above cash flow $R$. Thus, in the current case with $\varphi>\bar{\varphi}$ the support is $\left[\bar{r}_{D}, R\right)$ 
Table 1: Means of key variables by country.

Detailed explanations of variables are given in the Variables Section of the Appendix. No Switching is a binary indicator of not having changed the main bank since 1998. Days is number of days the bank needed to approve the last loan of the borrower. React is an ordinal score, higher values indicate more lenient reaction by the bank to a sudden non-payment by the borrower. Ccost is capital cost, checking is an indicator for having a checking account. Soft signal is a score indicating soft information about non-financial problems of growth.

\begin{tabular}{lcccccc}
\hline \hline country & \multicolumn{5}{c}{ Mean } \\
& No Switching & Days & React & Ccost & Checking & Soft Signal \\
\hline Albania & 0.74 & 53.94 & 3.02 & 2.59 & 0.96 & 8.29 \\
Armenia & 0.78 & 24.91 & 2.90 & 2.52 & 0.79 & 11.29 \\
Azerbaijan & 0.74 & 21.66 & 2.17 & 2.20 & 0.82 & 12.90 \\
Belarus & 0.74 & 18.91 & 2.92 & 2.78 & 0.84 & 9.75 \\
Bosnia & 0.72 & 36.75 & 3.00 & 2.79 & 0.07 & 10.01 \\
Bulgaria & 0.70 & 43.69 & 2.97 & 2.88 & 0.93 & 10.17 \\
Croatia & 0.71 & 38.39 & 2.70 & 2.27 & 0.21 & 11.16 \\
Czech Rep & 0.88 & 43.22 & 3.03 & 2.53 & 0.99 & 10.68 \\
Estonia & 0.93 & 12.63 & 2.27 & 2.01 & 0.97 & 11.05 \\
Georgia & 0.64 & 23.88 & 2.90 & 2.53 & 0.66 & 9.57 \\
Hungary & 0.80 & 27.96 & 2.87 & 2.31 & 0.99 & 11.76 \\
Kazakhstan & 0.77 & 21.18 & 2.64 & 2.16 & 0.88 & 11.99 \\
Kyrgyzstan & 0.58 & 13.78 & 2.67 & 2.40 & 0.82 & 11.15 \\
Latvia & 0.80 & 17.95 & 2.45 & 2.01 & 0.97 & 10.86 \\
Lithuania & 0.77 & 23.63 & 2.54 & 1.99 & 0.99 & 10.61 \\
Macedonia & 0.77 & 33.21 & 2.53 & 2.38 & 0.10 & 10.77 \\
Moldova & 0.87 & 13.16 & 2.71 & 2.95 & 0.65 & 9.15 \\
Poland & 0.76 & 24.46 & 2.56 & 3.17 & 0.93 & 9.02 \\
Romania & 0.74 & 21.36 & 3.04 & 2.80 & 0.98 & 9.63 \\
Russia & 0.68 & 14.94 & 2.55 & 2.24 & 0.92 & 10.59 \\
Serbia & 0.56 & 14.30 & 2.67 & 2.78 & 0.09 & 10.43 \\
Slovak Rep & 0.75 & 63.22 & 2.95 & 2.58 & 0.99 & 10.04 \\
Slovenia & 0.66 & 24.85 & 2.77 & 2.20 & 1.00 & 12.22 \\
Ukraine & 0.69 & 14.79 & 2.77 & 2.62 & 0.94 & 10.08 \\
\hline Total & 0.74 & 25.61 & 2.31 & 2.53 & 0.82 & 10.46 \\
\hline \hline Source: BEEPS 2002, except variable checking & which is BEEPS 2005. &
\end{tabular}


$[\mathrm{h}]$

Table 2: Means of Macro-level variables by country

Information is an information sharing index (Brown et al 2007), 1996-2000: the index adds 1 point if $\mathrm{PCR} / \mathrm{PB}$ exists for more than 3 years; 1 point if individuals and firms are covered; 1 point if positive and negative data are collected; 1 point if $\mathrm{PCR} / \mathrm{PCB}$ distributes data which is at least 2 years old; 1 point if threshold loan is below per capita GDP. Foreign Bank is the share of banking sector assets controlled by banks with a majority foreign ownership, taken over 1996-2000 (Brown et al 2007), Av. GDP is the average per capita GDP during 1996-2000, Creditor rights is the creditor rights index based on Brown et al (2007), $C R$ is the banking concentration ratio taken from -asset share of the largest five banks, and $N P L$ is the share of non-performing loans in total loans.

\begin{tabular}{lccccccc}
\hline \hline country & & \multicolumn{9}{c}{ Mean } & & & \\
& Information & Foreign Bank & Av. GDP & Inflation & Creditor Rights & CR & NPL \\
\hline Albania & 0.00 & 27.10 & 1.20 & 0.10 & 3.00 & 86.70 & 3.75 \\
Armenia & 0.00 & 44.90 & 0.60 & -0.80 & 2.00 & 54.60 & 1.97 \\
Azerbaijan & 0.00 & 4.40 & 0.60 & 1.80 & 3.00 & 71.90 & 2.67 \\
Belarus & 0.00 & 3.60 & 0.80 & 168.60 & 2.00 & 81.10 & 2.72 \\
Bosnia & 0.00 & 12.70 & 1.20 & 1.90 & 3.00 & 56.00 & 2.63 \\
Bulgaria & 0.80 & 59.10 & 1.60 & 10.30 & 1.50 & 56.50 & 2.39 \\
Croatia & 0.00 & 62.20 & 4.20 & 5.30 & 3.00 & 66.50 & 2.99 \\
Czech Rep & 0.00 & 51.90 & 5.50 & 3.90 & 3.00 & 69.00 & 3.68 \\
Estonia & 4.00 & 93.60 & 4.00 & 4.00 & 3.00 & 98.90 & 0.26 \\
Georgia & 0.00 & 16.80 & 0.70 & 4.10 & 2.00 & 57.30 & 1.97 \\
Hungary & 3.80 & 64.50 & 4.50 & 9.80 & 1.00 & 62.50 & 1.13 \\
Kazakhstan & 3.60 & 19.80 & 1.20 & 18.70 & 3.00 & 70.20 & 0.74 \\
Kyrgyzstan & 0.00 & 20.60 & 0.30 & 13.20 & 3.00 & 51.40 & 2.79 \\
Latvia & 0.00 & 74.20 & 3.20 & 2.70 & 3.00 & 66.20 & 1.61 \\
Lithuania & 4.60 & 45.90 & 3.30 & 1.00 & 2.00 & 87.90 & 2.38 \\
Macedonia & 2.00 & 32.50 & 1.80 & 6.60 & 3.00 & 72.10 & 3.84 \\
Moldova & 0.00 & 37.10 & 0.30 & 31.30 & 2.00 & 71.00 & 3.03 \\
Poland & 0.00 & 61.00 & 4.50 & 10.10 & 1.00 & 57.40 & 2.82 \\
Romania & 0.60 & 45.20 & 1.40 & 45.70 & 2.00 & 65.20 & 1.34 \\
Russia & 0.00 & 10.10 & 1.80 & 20.80 & 1.00 & 42.80 & 2.78 \\
Serbia & 0.00 & 0.50 & 1.00 & 8.80 & 3.00 & 42.40 & 3.33 \\
Slovak Rep & 1.20 & 33.40 & 3.70 & 60.40 & 2.00 & 66.50 & 3.27 \\
Slovenia & 2.80 & 10.10 & 9.50 & 12.00 & 2.00 & 69.00 & 2.23 \\
Ukraine & 0.00 & 10.80 & 0.60 & 28.20 & 2.00 & 37.00 & 3.48 \\
\hline Total & 0.85 & 33.95 & 2.42 & 21.05 & 2.14 & 61.83 & 2.55 \\
\hline \hline Source: BEFS & 2002 & & & & & &
\end{tabular}

Source: BEEPS 2002. 
Table 3: Cross-section estimation results: Days.

Dependent variable is the days from time of loan application until it is approved. The first row is the total sample, the second and third rows are the sample for smalland large firms, respectively. They show that the effect is largely driven by small firms, since we conjecture soft information plays little role for large firms. Standard errors are adjusted for cluster effects at the country level. Sector dummies not reported. Stars $*, * *, * * *$, indicate significance at $10,5,1 \%$ respectively.

\begin{tabular}{lccc}
\hline \hline variable & $(1)$ & $(2)$ & $(3)$ \\
& All & Small & Large \\
\hline information & $3.523^{* *}$ & $4.065^{* * *}$ & 1.689 \\
& $(1.489)$ & $(1.280)$ & $(3.079)$ \\
post transition firm & -2.223 & -1.350 & -4.737 \\
& $(1.654)$ & $(2.690)$ & $(3.573)$ \\
transition firm & 0.785 & 2.774 & -5.983 \\
& $(2.384)$ & $(3.284)$ & $(4.680)$ \\
state owned firm & -0.003 & 0.015 & -0.028 \\
& $(0.040)$ & $(0.043)$ & $(0.068)$ \\
concentration & -0.215 & -0.217 & -0.200 \\
& $(0.153)$ & $(0.131)$ & $(0.300)$ \\
non performing loan & $0.271^{*}$ & $0.238^{*}$ & 0.387 \\
& $(0.142)$ & $(0.134)$ & $(0.230)$ \\
creditor rights & $-6.405^{* *}$ & $-8.881^{* * *}$ & 4.420 \\
& $(2.886)$ & $(2.631)$ & $(5.595)$ \\
bank reform index & -1.426 & -0.368 & -10.334 \\
& $(5.685)$ & $(5.539)$ & $(8.958)$ \\
foreign bank share & $0.381^{* * *}$ & $0.366^{* * *}$ & $0.498^{*}$ \\
& $(0.131)$ & $(0.112)$ & $(0.240)$ \\
private credit/GDP & 0.359 & $0.434^{*}$ & 0.172 \\
& $(0.291)$ & $(0.217)$ & $(0.567)$ \\
collateral law & $-9.769^{* * *}$ & $-10.919^{* * *}$ & -4.040 \\
& $(2.143)$ & $(1.930)$ & $(4.199)$ \\
GDP per capita & -4.791 & $-6.887^{*}$ & 3.723 \\
& $(3.355)$ & $(3.512)$ & $(5.209)$ \\
inflation & -7.093 & $-8.524^{*}$ & -1.817 \\
& $(4.967)$ & $(4.130)$ & $(10.479)$ \\
constant & $58.278^{* * *}$ & $69.129^{* * *}$ & 46.353 \\
R-squared & $(11.695)$ & $(11.282)$ & $(27.195)$ \\
Number of obs. & 0.12 & 0.10 & 0.22 \\
\hline \hline & 2064 & 1638 & 426 \\
\hline
\end{tabular}


Table 4: Cross-section estimation results: React.

React shows banks' reaction as perceived by borrowers. It is based on the hypothetical question, "If your firm were to fall behind in its bank repayments, which of the following would best describe how you would expect the bank to react?" Possible answers include: a) Extend the term of the loan without changing the conditions $(=3)$ b) Extend the term of the loan but increase the interest rate $(=2)$ c) Begin legal proceedings to take possession of some assets of the firm $(=1)$. Regressions are ordered probit. The first row is the total sample, the second row is the sample for small firms, the third one is the sample for large firms. Standard errors are adjusted for cluster effects at the country level. Sector dummies not reported. Stars $*, * *, * * *$, indicate significance at 10,5 , $1 \%$ respectively.

\begin{tabular}{|c|c|c|c|}
\hline variable & $\begin{array}{l}\text { (1) } \\
\text { All }\end{array}$ & $\begin{array}{c}(2) \\
\text { Small }\end{array}$ & $\begin{array}{c}(3) \\
\text { Large }\end{array}$ \\
\hline information & $\begin{array}{c}0.102^{* * *} \\
(0.039)\end{array}$ & $\begin{array}{c}0.120^{* * *} \\
(0.044)\end{array}$ & $\begin{array}{c}0.030 \\
(0.056)\end{array}$ \\
\hline post transition firm & $\begin{array}{l}-0.167^{*} \\
(0.089)\end{array}$ & $\begin{array}{c}-0.217^{* *} \\
(0.105)\end{array}$ & $\begin{array}{c}0.092 \\
(0.141)\end{array}$ \\
\hline transition firm & $\begin{array}{l}-0.106 \\
(0.091)\end{array}$ & $\begin{array}{l}-0.111 \\
(0.107)\end{array}$ & $\begin{array}{l}-0.169 \\
(0.173)\end{array}$ \\
\hline state owned firm & $\begin{array}{c}0.000 \\
(0.001)\end{array}$ & $\begin{array}{l}-0.001 \\
(0.001)\end{array}$ & $\begin{array}{c}0.002 \\
(0.002)\end{array}$ \\
\hline concentration & $\begin{array}{l}-0.003 \\
(0.004)\end{array}$ & $\begin{array}{l}-0.004 \\
(0.005)\end{array}$ & $\begin{array}{c}0.002 \\
(0.005)\end{array}$ \\
\hline non performing loan & $\begin{array}{l}-0.003 \\
(0.005)\end{array}$ & $\begin{array}{l}-0.002 \\
(0.005)\end{array}$ & $\begin{array}{l}-0.009 \\
(0.006)\end{array}$ \\
\hline creditor rights & $\begin{array}{l}-0.056 \\
(0.067)\end{array}$ & $\begin{array}{l}-0.082 \\
(0.074)\end{array}$ & $\begin{array}{c}0.036 \\
(0.081)\end{array}$ \\
\hline bank reform index & $\begin{array}{c}-0.692^{* * *} \\
(0.175)\end{array}$ & $\begin{array}{c}-0.629 * * * \\
(0.194)\end{array}$ & $\begin{array}{c}-0.896^{* * *} \\
(0.231)\end{array}$ \\
\hline foreign bank share & $\begin{array}{c}0.013^{* * *} \\
(0.003)\end{array}$ & $\begin{array}{c}0.013^{* * *} \\
(0.003)\end{array}$ & $\begin{array}{c}0.009 \\
(0.005)\end{array}$ \\
\hline private credit/GDP & $\begin{array}{c}0.013 \\
(0.010)\end{array}$ & $\begin{array}{c}0.011 \\
(0.011)\end{array}$ & $\begin{array}{l}0.022^{*} \\
(0.013)\end{array}$ \\
\hline GDP per capita & $\begin{array}{c}0.067 \\
(0.089)\end{array}$ & $\begin{array}{c}0.040 \\
(0.113)\end{array}$ & $\begin{array}{c}0.175 \\
(0.166)\end{array}$ \\
\hline inflation & $\begin{array}{c}-0.481^{* * *} \\
(0.160)\end{array}$ & $\begin{array}{c}-0.348^{* *} \\
(0.173)\end{array}$ & $\begin{array}{c}-1.022^{* * *} \\
(0.225)\end{array}$ \\
\hline constant & $\begin{array}{c}-2.433^{* * *} \\
(0.262)\end{array}$ & $\begin{array}{c}-2.444^{* * *} \\
(0.283)\end{array}$ & $\begin{array}{c}-3.023 * * * \\
(0.789)\end{array}$ \\
\hline constant & $\begin{array}{c}-1.334^{* * *} \\
(0.282)\end{array}$ & $\begin{array}{c}-1.365^{* * *} \\
(0.286)\end{array}$ & $\begin{array}{c}-1.787^{* *} \\
(0.791)\end{array}$ \\
\hline constant & $\begin{array}{l}0.075 \\
0.075\end{array}$ & $\begin{array}{l}-0.000 \\
-0.000\end{array}$ & $\begin{array}{l}-0.179 \\
-0.179\end{array}$ \\
\hline Pseudo R-Squared & 0.04 & 0.03 & 0.08 \\
\hline Number of obs. & 1937 & 1511 & 426 \\
\hline
\end{tabular}


Table 5: Cross-section estimation results: Checking account.

Checking account indicates the existence of checking account for the borrower. The first row is the total sample, the second row is the sample for small firms, the third one is the sample for large firms. All columns are based on probit estimation. Standard errors are adjusted for cluster effects at the country level. Sector dummies not reported. Stars ${ }^{*},{ }^{* *},{ }^{* * *}$,indicate significance at $10,5,1 \%$, respectively.

\begin{tabular}{lccc}
\hline \hline variable & $(1)$ & $(2)$ & $(3)$ \\
& All & Small & Large \\
\hline information & $0.115^{* * *}$ & $0.115^{* * *}$ & $0.163^{* * *}$ \\
& $(0.023)$ & $(0.027)$ & $(0.055)$ \\
post transition firm & -0.081 & -0.066 & 0.039 \\
& $(0.059)$ & $(0.073)$ & $(0.125)$ \\
transition firm & 0.096 & 0.080 & $0.215^{*}$ \\
& $(0.063)$ & $(0.078)$ & $(0.128)$ \\
state owned firm & 0.001 & -0.000 & -0.002 \\
& $(0.001)$ & $(0.001)$ & $(0.001)$ \\
concentration & $-0.017^{* * *}$ & $-0.015^{* * *}$ & $-0.025^{* * *}$ \\
& $(0.002)$ & $(0.002)$ & $(0.005)$ \\
non performing loan & $-0.069^{* * *}$ & $-0.066^{* * *}$ & $-0.086^{* * *}$ \\
& $(0.004)$ & $(0.005)$ & $(0.011)$ \\
creditor rights & 0.008 & -0.006 & $0.248^{* *}$ \\
& $(0.047)$ & $(0.054)$ & $(0.125)$ \\
bank reform index & $2.739^{* * *}$ & $2.480^{* * *}$ & $3.946^{* * *}$ \\
foreign bank share & $(0.116)$ & $(0.134)$ & $(0.274)$ \\
& $-0.032^{* * *}$ & $-0.028^{* * *}$ & $-0.054^{* * *}$ \\
private credit/GDP & $(0.002)$ & $(0.002)$ & $(0.005)$ \\
& $-0.090^{* * *}$ & $-0.083^{* * *}$ & $-0.129^{* * *}$ \\
GDP per capita & $(0.004)$ & $(0.004)$ & $(0.010)$ \\
& $0.553^{* * *}$ & $0.536^{* * *}$ & $0.783^{* * *}$ \\
inflation & $(0.047)$ & $(0.055)$ & $(0.112)$ \\
& $0.066^{* * *}$ & $0.060^{* * *}$ & $0.083^{* * *}$ \\
constant & $(0.005)$ & $(0.006)$ & $(0.012)$ \\
& $-2.446^{* * *}$ & $-2.424^{* * *}$ & $-3.498^{* * *}$ \\
Pseudo Rsquared & $(0.336)$ & $(0.322)$ & $(0.711)$ \\
Number of obs. & 0.13 & 0.13 & 0.19 \\
\hline \hline & 7713 & 5453 & 2260 \\
\hline
\end{tabular}


$[\mathrm{h}]$

Table 6: Cross-section estimation results: Switching from the main bank.

Switching is the dependent variable. It equals 1 if the firm replies "yes" to the following question: Has your firm changed its main bank (the single bank with which your firm has the closest relationship)? Information is an index of shared information (Brown et al 2007)- it is 0 for countries with no sharing. Soft signal 1 is a summary measure that proxies the sign of soft information acquired for the firm and shows how protected the firm is from each of the 19 non-financial problems discussed: range $[0.21 ; 1]$. Soft signal 2 is a proxy of management quality (1-3). Higher values of soft signal indicate good soft signal. All columns are based on probit estimation. Sector dummies not reported. Standard errors are adjusted for cluster effects at the country level. Stars *, **, ***, indicate significance at 10, 5, 1 $\%$, respectively.

\begin{tabular}{|c|c|c|c|c|c|c|}
\hline variable & $\begin{array}{l}\text { (1) } \\
\text { All }\end{array}$ & $\begin{array}{c}(2) \\
\text { Small }\end{array}$ & $\begin{array}{c}(3) \\
\text { Large }\end{array}$ & $\begin{array}{l}\text { (4) } \\
\text { All }\end{array}$ & $\begin{array}{c}(5) \\
\text { Small }\end{array}$ & $\begin{array}{c}(6) \\
\text { Large }\end{array}$ \\
\hline soft signal (1) & $\begin{array}{c}-0.239^{*} \\
(0.123)\end{array}$ & $\begin{array}{c}-0.274^{* *} \\
(0.132)\end{array}$ & $\begin{array}{l}-0.008 \\
(0.345)\end{array}$ & $\begin{array}{c}-0.249^{* *} \\
(0.123)\end{array}$ & $\begin{array}{c}-0.289^{* *} \\
(0.133)\end{array}$ & $\begin{array}{c}0.017 \\
(0.347)\end{array}$ \\
\hline soft signal (2) & & & & $\begin{array}{c}-0.074^{* * *} \\
(0.026)\end{array}$ & $\begin{array}{c}-0.069 * * * \\
(0.021)\end{array}$ & $\begin{array}{l}-0.092 \\
(0.069)\end{array}$ \\
\hline information & $\begin{array}{l}-0.011 \\
(0.025)\end{array}$ & $\begin{array}{l}-0.013 \\
(0.028)\end{array}$ & $\begin{array}{l}-0.010 \\
(0.067)\end{array}$ & $\begin{array}{l}-0.008 \\
(0.026)\end{array}$ & $\begin{array}{l}-0.009 \\
(0.028)\end{array}$ & $\begin{array}{l}-0.015 \\
(0.067)\end{array}$ \\
\hline information ${ }^{*}$ soft & $\begin{array}{l}-0.007 \\
(0.006)\end{array}$ & $\begin{array}{l}-0.008 \\
(0.006)\end{array}$ & $\begin{array}{l}-0.002 \\
(0.016)\end{array}$ & $\begin{array}{l}-0.007 \\
(0.006)\end{array}$ & $\begin{array}{l}-0.007 \\
(0.006)\end{array}$ & $\begin{array}{l}-0.004 \\
(0.016)\end{array}$ \\
\hline post transition firm & $\begin{array}{c}-0.161^{* *} \\
(0.067)\end{array}$ & $\begin{array}{c}-0.165^{* *} \\
(0.081)\end{array}$ & $\begin{array}{l}-0.076 \\
(0.146)\end{array}$ & $\begin{array}{c}-0.185^{* * *} \\
(0.068)\end{array}$ & $\begin{array}{c}-0.186^{* *} \\
(0.082)\end{array}$ & $\begin{array}{l}-0.090 \\
(0.147)\end{array}$ \\
\hline transition firm & $\begin{array}{l}-0.078 \\
(0.075)\end{array}$ & $\begin{array}{l}-0.097 \\
(0.088)\end{array}$ & $\begin{array}{c}0.047 \\
(0.170)\end{array}$ & $\begin{array}{l}-0.081 \\
(0.075)\end{array}$ & $\begin{array}{l}-0.100 \\
(0.089)\end{array}$ & $\begin{array}{c}0.071 \\
(0.172)\end{array}$ \\
\hline state owned firm & $\begin{array}{l}-0.001 \\
(0.001)\end{array}$ & $\begin{array}{l}-0.001 \\
(0.001)\end{array}$ & $\begin{array}{l}-0.003 \\
(0.002)\end{array}$ & $\begin{array}{l}-0.001 \\
(0.001)\end{array}$ & $\begin{array}{l}-0.001 \\
(0.001)\end{array}$ & $\begin{array}{l}-0.003 \\
(0.002)\end{array}$ \\
\hline concentration & $\begin{array}{c}-0.008 * * * \\
(0.002)\end{array}$ & $\begin{array}{c}-0.009 * * * \\
(0.003)\end{array}$ & $\begin{array}{l}-0.007 \\
(0.006)\end{array}$ & $\begin{array}{c}-0.008 * * * \\
(0.002)\end{array}$ & $\begin{array}{c}-0.009 * * * \\
(0.003)\end{array}$ & $\begin{array}{l}-0.008 \\
(0.006)\end{array}$ \\
\hline non performing loan & $\begin{array}{l}-0.004 \\
(0.002)\end{array}$ & $\begin{array}{l}-0.003 \\
(0.003)\end{array}$ & $\begin{array}{l}-0.005 \\
(0.007)\end{array}$ & $\begin{array}{l}-0.004 \\
(0.002)\end{array}$ & $\begin{array}{l}-0.003 \\
(0.003)\end{array}$ & $\begin{array}{l}-0.004 \\
(0.007)\end{array}$ \\
\hline creditor rights & $\begin{array}{l}-0.011 \\
(0.038)\end{array}$ & $\begin{array}{c}0.015 \\
(0.041)\end{array}$ & $\begin{array}{l}-0.145 \\
(0.098)\end{array}$ & $\begin{array}{l}-0.008 \\
(0.038)\end{array}$ & $\begin{array}{c}0.018 \\
(0.041)\end{array}$ & $\begin{array}{l}-0.146 \\
(0.099)\end{array}$ \\
\hline bank reform index & $\begin{array}{c}0.256^{* *} \\
(0.119)\end{array}$ & $\begin{array}{c}0.258^{* *} \\
(0.130)\end{array}$ & $\begin{array}{c}0.208 \\
(0.313)\end{array}$ & $\begin{array}{c}0.242^{* *} \\
(0.119)\end{array}$ & $\begin{array}{l}0.240^{*} \\
(0.131)\end{array}$ & $\begin{array}{c}0.241 \\
(0.314)\end{array}$ \\
\hline foreign bank share & $\begin{array}{c}-0.010^{* * *} \\
(0.002)\end{array}$ & $\begin{array}{c}-0.010^{* * *} \\
(0.002)\end{array}$ & $\begin{array}{l}-0.006 \\
(0.007)\end{array}$ & $\begin{array}{c}-0.010 * * * \\
(0.002)\end{array}$ & $\begin{array}{c}-0.010 * * * \\
(0.002)\end{array}$ & $\begin{array}{l}-0.006 \\
(0.007)\end{array}$ \\
\hline private credit/GDP & $\begin{array}{c}-0.019 * * * \\
(0.005)\end{array}$ & $\begin{array}{c}-0.017^{* * *} \\
(0.006)\end{array}$ & $\begin{array}{c}-0.038 * * * \\
(0.014)\end{array}$ & $\begin{array}{c}-0.019 * * * \\
(0.005)\end{array}$ & $\begin{array}{c}-0.017^{* * *} \\
(0.006)\end{array}$ & $\begin{array}{c}-0.039 * * * \\
(0.014)\end{array}$ \\
\hline GDP per capita & $\begin{array}{c}0.143^{* *} \\
(0.062)\end{array}$ & $\begin{array}{c}0.137^{* *} \\
(0.067)\end{array}$ & $\begin{array}{c}0.226 \\
(0.167)\end{array}$ & $\begin{array}{c}0.144^{* *} \\
(0.062)\end{array}$ & $\begin{array}{c}0.138^{* *} \\
(0.067)\end{array}$ & $\begin{array}{c}0.230 \\
(0.167)\end{array}$ \\
\hline inflation & $\begin{array}{c}0.079 \\
(0.105)\end{array}$ & $\begin{array}{c}0.126 \\
(0.115)\end{array}$ & $\begin{array}{l}-0.143 \\
(0.273)\end{array}$ & $\begin{array}{c}0.063 \\
(0.105)\end{array}$ & $\begin{array}{c}0.106 \\
(0.115)\end{array}$ & $\begin{array}{l}-0.134 \\
(0.273)\end{array}$ \\
\hline constant & $\begin{array}{c}0.061 \\
(0.284)\end{array}$ & $\begin{array}{c}0.364 \\
(0.419)\end{array}$ & $\begin{array}{c}1.031 \\
(0.785)\end{array}$ & $\begin{array}{c}0.729^{* *} \\
(0.359)\end{array}$ & $\begin{array}{c}0.624 \\
(0.432)\end{array}$ & $\begin{array}{c}0.323 \\
(0.937)\end{array}$ \\
\hline Pseudo R2 & 0.02 & 0.02 & 0.05 & 0.02 & 0.02 & 0.05 \\
\hline Number of obs. & 3531 & 2984 & 547 & 3490 & 2945 & 545 \\
\hline
\end{tabular}


[h]

Table 7: Cross-section estimation results: Cost of capital.

The first and forth columns are ordered probit regression of the total sample, the second and fifth are for small firms, and third and sixth -for large firms. Sector dummies not reported. Standard errors are adjusted for cluster effects at the country level. Stars ${ }^{*},{ }^{*},{ }^{* * *}$,indicate significance at $1,5,10 \%$, respectively.

\begin{tabular}{|c|c|c|c|c|c|c|}
\hline variable & $\begin{array}{l}\text { (1) } \\
\text { All }\end{array}$ & $\begin{array}{c}(2) \\
\text { Small }\end{array}$ & $\begin{array}{c}(3) \\
\text { Large }\end{array}$ & $\begin{array}{l}\text { (4) } \\
\text { All }\end{array}$ & $\begin{array}{c}5) \\
\text { Small }\end{array}$ & $\begin{array}{c}(6) \\
\text { Large }\end{array}$ \\
\hline soft signal (1) & $\begin{array}{c}-2.771^{* * *} \\
(0.102)\end{array}$ & $\begin{array}{c}-2.818^{* * *} \\
(0.110)\end{array}$ & $\begin{array}{c}-2.595^{* * * *} \\
(0.285)\end{array}$ & $\begin{array}{c}-2.775^{* * *} \\
(0.103)\end{array}$ & $\begin{array}{c}-2.827^{* * *} \\
(0.111)\end{array}$ & $\begin{array}{c}-2.576^{* * *} \\
(0.285)\end{array}$ \\
\hline soft signal (2) & & & & $\begin{array}{c}-0.040^{* *} \\
(0.020)\end{array}$ & $\begin{array}{c}-0.040^{*} \\
(0.022)\end{array}$ & $\begin{array}{c}0.003 \\
(0.055)\end{array}$ \\
\hline information & $\begin{array}{c}-0.107^{* * *} \\
(0.020)\end{array}$ & $\begin{array}{c}-0.104^{* * *} \\
(0.022)\end{array}$ & $\begin{array}{c}-0.097^{*} \\
(0.054)\end{array}$ & $\begin{array}{c}-0.106^{* * *} \\
(0.020)\end{array}$ & $\begin{array}{c}-0.102^{* * *} \\
(0.022)\end{array}$ & $\begin{array}{c}-0.098^{*} \\
(0.054)\end{array}$ \\
\hline information*soft & $\begin{array}{c}0.002 \\
(0.005)\end{array}$ & $\begin{array}{c}0.002 \\
(0.005)\end{array}$ & $\begin{array}{c}0.000 \\
(0.013)\end{array}$ & $\begin{array}{c}0.001 \\
(0.005)\end{array}$ & $\begin{array}{c}0.001 \\
(0.005)\end{array}$ & $\begin{array}{c}0.000 \\
(0.013)\end{array}$ \\
\hline post transition firm & $\begin{array}{l}-0.027 \\
(0.054)\end{array}$ & $\begin{array}{l}-0.074 \\
(0.065)\end{array}$ & $\begin{array}{l}-0.016 \\
(0.115)\end{array}$ & $\begin{array}{l}-0.045 \\
(0.054)\end{array}$ & $\begin{array}{l}-0.093 \\
(0.066)\end{array}$ & $\begin{array}{l}-0.015 \\
(0.115)\end{array}$ \\
\hline transition firm & $\begin{array}{l}-0.015 \\
(0.060)\end{array}$ & $\begin{array}{l}-0.036 \\
(0.071)\end{array}$ & $\begin{array}{l}-0.217 \\
(0.134)\end{array}$ & $\begin{array}{l}-0.012 \\
(0.060)\end{array}$ & $\begin{array}{l}-0.033 \\
(0.071)\end{array}$ & $\begin{array}{l}-0.206 \\
(0.135)\end{array}$ \\
\hline state owned firm & $\begin{array}{l}-0.001 \\
(0.001)\end{array}$ & $\begin{array}{c}-0.001 \\
(0.001)\end{array}$ & $\begin{array}{c}-0.002 \\
(0.001)\end{array}$ & $\begin{array}{l}-0.001 \\
(0.001)\end{array}$ & $\begin{array}{l}-0.001 \\
(0.001)\end{array}$ & $\begin{array}{c}-0.002 \\
(0.001)\end{array}$ \\
\hline concentration & $\begin{array}{c}-0.007 * * * \\
(0.002)\end{array}$ & $\begin{array}{c}-0.007 * * * \\
(0.002)\end{array}$ & $\begin{array}{c}-0.010^{* *} \\
(0.005)\end{array}$ & $\begin{array}{c}-0.007^{* * *} \\
(0.002)\end{array}$ & $\begin{array}{c}-0.007^{* * *} \\
(0.002)\end{array}$ & $\begin{array}{c}-0.010^{* *} \\
(0.005)\end{array}$ \\
\hline non performing loan & $\begin{array}{l}-0.002 \\
(0.002)\end{array}$ & $\begin{array}{l}-0.002 \\
(0.002)\end{array}$ & $\begin{array}{l}-0.000 \\
(0.005)\end{array}$ & $\begin{array}{c}-0.002 \\
(0.002)\end{array}$ & $\begin{array}{l}-0.002 \\
(0.002)\end{array}$ & $\begin{array}{l}-0.000 \\
(0.005)\end{array}$ \\
\hline creditor rights & $\begin{array}{c}-0.096^{* * *} \\
(0.030)\end{array}$ & $\begin{array}{c}-0.087^{* * *} \\
(0.032)\end{array}$ & $\begin{array}{l}-0.099 \\
(0.078)\end{array}$ & $\begin{array}{c}-0.092^{* * *} \\
(0.030)\end{array}$ & $\begin{array}{c}-0.082^{* *} \\
(0.032)\end{array}$ & $\begin{array}{l}-0.102 \\
(0.078)\end{array}$ \\
\hline bank reform index & $\begin{array}{c}0.679^{* * *} \\
(0.092)\end{array}$ & $\begin{array}{c}0.642^{* * *} \\
(0.099)\end{array}$ & $\begin{array}{c}0.769^{* * *} \\
(0.250)\end{array}$ & $\begin{array}{c}0.659^{* * *} \\
(0.092)\end{array}$ & $\begin{array}{c}0.616^{* * *} \\
(0.100)\end{array}$ & $\begin{array}{c}0.774^{* * *} \\
(0.250)\end{array}$ \\
\hline foreign bank share & $\begin{array}{c}-0.005^{* * *} \\
(0.002)\end{array}$ & $\begin{array}{c}-0.004^{* *} \\
(0.002)\end{array}$ & $\begin{array}{l}-0.005 \\
(0.005)\end{array}$ & $\begin{array}{c}-0.005^{* * *} \\
(0.002)\end{array}$ & $\begin{array}{c}-0.004^{* *} \\
(0.002)\end{array}$ & $\begin{array}{l}-0.005 \\
(0.005)\end{array}$ \\
\hline private credit/GDP & $\begin{array}{l}-0.002 \\
(0.004)\end{array}$ & $\begin{array}{c}0.000 \\
(0.004)\end{array}$ & $\begin{array}{c}-0.017 \\
(0.011)\end{array}$ & $\begin{array}{l}-0.002 \\
(0.004)\end{array}$ & $\begin{array}{c}0.000 \\
(0.004)\end{array}$ & $\begin{array}{c}-0.017 \\
(0.011)\end{array}$ \\
\hline GDP per capita & $\begin{array}{c}-0.180^{* * *} \\
(0.047)\end{array}$ & $\begin{array}{c}-0.185^{* * *} \\
(0.050)\end{array}$ & $\begin{array}{l}-0.136 \\
(0.128)\end{array}$ & $\begin{array}{c}-0.175^{* * *} \\
(0.047)\end{array}$ & $\begin{array}{c}-0.178^{* * *} \\
(0.050)\end{array}$ & $\begin{array}{l}-0.137 \\
(0.128)\end{array}$ \\
\hline inflation & $\begin{array}{c}0.529^{* * *} \\
(0.081)\end{array}$ & $\begin{array}{c}0.449^{* * *} \\
(0.089)\end{array}$ & $\begin{array}{c}1.009^{* * *} \\
(0.214)\end{array}$ & $\begin{array}{c}0.511^{* * * *} \\
(0.081)\end{array}$ & $\begin{array}{c}0.425^{* * *} \\
(0.089)\end{array}$ & $\begin{array}{c}1.010^{* * *} \\
(0.214)\end{array}$ \\
\hline constant & $\begin{array}{c}-1.912^{* * *} \\
(0.278)\end{array}$ & $\begin{array}{c}-1.924^{* * *} \\
(0.334)\end{array}$ & $\begin{array}{c}-2.030^{* * *} \\
(0.629)\end{array}$ & $\begin{array}{c}-2.093^{* * *} \\
(0.236)\end{array}$ & $\begin{array}{c}-2.170^{* * *} \\
(0.256)\end{array}$ & $\begin{array}{c}-2.012^{* * *} \\
(0.646)\end{array}$ \\
\hline constant & $\begin{array}{c}-1.226^{* * *} \\
(0.277)\end{array}$ & $\begin{array}{c}-1.260^{* * *} \\
(0.333)\end{array}$ & $\begin{array}{c}-1.195^{*} \\
(0.626)\end{array}$ & $\begin{array}{c}-1.404^{* * *} \\
(0.235)\end{array}$ & $\begin{array}{c}-1.502^{* * *} \\
(0.255)\end{array}$ & $\begin{array}{c}-1.181^{*} \\
(0.644)\end{array}$ \\
\hline constant & $\begin{array}{l}-0.362 \\
(0.277)\end{array}$ & $\begin{array}{l}-0.383 \\
(0.333)\end{array}$ & $\begin{array}{c}-0.348 \\
(0.626)\end{array}$ & $\begin{array}{c}-0.542^{* *} \\
(0.235)\end{array}$ & $\begin{array}{c}-0.629^{* *} \\
(0.254)\end{array}$ & $\begin{array}{c}-0.333 \\
(0.643)\end{array}$ \\
\hline $\begin{array}{l}\text { Pseudo R-squared } \\
\text { Number of obs. }\end{array}$ & 3643 & 3102 & 541 & 3601 & 3062 & 539 \\
\hline
\end{tabular}


Table 8: Panel estimation results: Cost of capital.

The first column is the fixed effects regression of the total sample, the second column is random effects estimation. The third one takes only small firms (Fixed effects), while the forth one takes large and medium firms (fixed effects). All estimations are ordered probit. Sector dummies not reported. Standard errors are adjusted for cluster effects at the country level. Stars ${ }^{*},{ }^{* *},{ }^{* * *}$,indicate significance, at $1,5,10 \%$, respectively.

\begin{tabular}{lcccc}
\hline \hline variable & $(1)$ & $(2)$ & $(3)$ & $(4)$ \\
& All(FE) & All $(\mathrm{RE})$ & Small(FE) & Large(FE) \\
\hline soft signal & $-2.051^{* * *}$ & $-2.573^{* * *}$ & $-2.162^{* * *}$ & $-1.999^{* * *}$ \\
& $(0.232)$ & $(0.075)$ & $(0.290)$ & $(0.458)$ \\
information & $-0.114^{*}$ & $-0.062^{* * *}$ & $-0.167^{* *}$ & -0.023 \\
& $(0.061)$ & $(0.011)$ & $(0.078)$ & $(0.124)$ \\
bank reform index & 0.359 & 0.038 & 0.141 & 0.495 \\
& $(0.256)$ & $(0.045)$ & $(0.342)$ & $(0.461)$ \\
foreign bank share & $-1.537^{* *}$ & 0.072 & -0.468 & $-2.601^{* *}$ \\
& $(0.713)$ & $(0.092)$ & $(0.953)$ & $(1.286)$ \\
private credit/GDP & $-0.023^{* *}$ & $0.005^{*}$ & -0.012 & $-0.029^{*}$ \\
& $(0.009)$ & $(0.003)$ & $(0.013)$ & $(0.017)$ \\
GDP per capita & $1.373^{* * *}$ & $-0.058^{*}$ & $1.117^{*}$ & 1.035 \\
& $(0.483)$ & $(0.032)$ & $(0.635)$ & $(0.960)$ \\
inflation & 0.001 & $0.001^{* * *}$ & 0.000 & 0.001 \\
& $(0.001)$ & $(0.000)$ & $(0.001)$ & $(0.002)$ \\
constant & $3.129^{* * *}$ & $4.209^{* * *}$ & $3.434^{* * *}$ & $3.404^{* * *}$ \\
& $(0.556)$ & $(0.090)$ & $(0.752)$ & $(0.928)$ \\
R-squared & 0.153 & 0.134 & 0.163 & 0.148 \\
Number of obs. & 4626 & 4626 & 3082 & 1544 \\
\hline \hline
\end{tabular}


b)Now suppose $\varphi<\bar{\varphi}$ (the bad signal defaulting borrowers are creditworthy). and Clearly, $r_{i}^{B D} \geq \bar{r}_{B D}$ because anything lower than that yields losses. Repeated undercutting arguments establish that the informed bank bids pure strategy breakeven $\bar{r}_{B D}$ for bad signal defaulting borrowers. The remainder of the proof is similar to case is similar, except that common support is now $\left[\bar{r}_{D}, \bar{r}_{B D}\right)$. Concluding, the common support of the c.d.f.'s of the two banks is therefore $\left[\bar{r}_{D}, \bar{r}_{B D} \wedge R\right.$ ).

Since the mixing distributions are increasing, equilibrium profits for each banks must be constant over any $r \in\left[\bar{r}_{D}, \bar{r}_{B D} \wedge R\right.$ ): the bank has to be indifferent for any bid. Thus,

But then,

$$
N_{G D}\left(p_{G D} r-I\right)\left(1-F_{u}^{D}(r)\right)=\text { constant. }
$$

so that

$$
N_{G D}\left(p_{G D} \bar{r}_{D}-I\right)=N_{G D}\left(p_{G D} r-I\right)\left(1-F_{u}^{D}(r)\right) .
$$

because the uninformed bank starts bidding from $\bar{r}_{D}, 1-F_{u}^{D}\left(\bar{r}_{D}\right)=1$. This gives us the expression for $F_{u}^{D}(r)$ :

$$
F_{u}^{D}(r)=1-\frac{p_{G D} \bar{r}_{D}-I}{p_{G D} r-I}
$$

Similarly,

$$
N_{G D}\left(p_{G D} r-I\right)\left(1-F_{i}^{G D}(r)\right)+N_{B D}\left(p_{B D} r-I\right)=0
$$

which yields

$$
F_{i}^{G D}(r)=1-\frac{N_{B D}\left(I-p_{B D} r\right)}{N_{G N}\left(p_{G D} r-I\right)}
$$

over $r \in\left[\bar{r}_{D}, \bar{r}_{B D} \wedge R\right)$, where $N_{G D}=\lambda \varphi(1-p)+(1-\lambda)(1-\varphi), N_{B D}=\lambda(1-\varphi)(1-$ $p)+(1-\lambda) \varphi$. It is now easy to verify that $\varphi F_{i}^{G D}(r)=\frac{p_{G D} r-p_{G D} \bar{r}_{D}}{p_{G D} r-I}=F_{u}^{D}(r)$. Since both banks randomize over the full support of their distribution functions, they cannot profitably deviate from their mixed strategies. Therefore, the distributions above represent the unique equilibrium of the bidding game for a given borrower. Observe that $F_{i}^{G D}\left(R^{-}\right)=1-\frac{N_{B D}\left(I-p_{B D} R\right)}{N_{G N}\left(p_{G D} R-I\right)}<1$, so that there is a point mass at $R$. Moreover, $F_{u}^{D}(R)=\varphi F_{i}^{G D}(R)<1$, so that the uninformed does not bid with probability $1-F_{u}^{D}(R)$ whenever $\varphi>\bar{\varphi}$.

Proof of proposition 2.2 Indeed, the incumbent lends to group $N$ and $G D$ and earns, so the incumbent bank's total profits can therefore be written as the sum of 
two terms:

$$
\pi_{\text {share }}=N_{N}\left(p_{N} \bar{r}_{N}-I\right)+N_{G D}\left(p_{G D} \bar{r}_{D}-I\right)
$$

However, the first term is 0 since, hard information sharing has leveled the playing field. Gross profits are now given by

$$
\begin{aligned}
N_{G D}\left(p_{G D} \bar{r}_{D}-I\right) & =\lambda \varphi p(1-p) \frac{\lambda(1-p)+1-\lambda}{\lambda p(1-p}-(\lambda \varphi(1-p)+(1-\lambda)(1-\varphi)) \\
& =(2 \varphi-1)(1-\lambda)
\end{aligned}
$$

Thus gross profits are linearly increasing in $\varphi$. Net profits can be obtained by subtracting the cost of monitoring $c\left(\varphi-\frac{1}{2}\right)^{2}$.

For $\varphi<\bar{\varphi}$ the analysis follows similar steps, remembering that the worst type yields 0 profits since the bank bids pure strategy break-even rate. For the proof of the uninformed bank's zero profits, see von Thadden (2004) or Hauswald and Marquez (2000).

Proof of Proposition 2.3 The construction of the common support is similar to the one in 2.1 , with a change in lower bound, $\left[\bar{r}, \bar{r}_{B D} \wedge R\right)$, since the uninformed breaks even by solving $\underline{r} \lambda p-I$.

As before, the informed bank bids different rates for $J=B D, G D, D$, while the uninformed bids $F_{u}(r)$ for any borrower, since it does not distinguish any types. It is clear, that as in the case with information sharing, the informed bank will bid $\bar{r}_{B D}$ for bad signal defaulting borrowers whenever $\varphi<\bar{\varphi}$, and will not bid otherwise.In equilibrium, the informed bank starts bidding at $\bar{r}$ for the $N$. It can bid up until the average break-even rate for the two other groups, that have lower quality, the $B D$ and $G D$ groups. The average break-even rate for these two groups is $\bar{r}_{D}$. For $G D$ it starts bidding at $\bar{r}_{D}$, up until $\bar{r}_{B D} \wedge R$. To see that this is an equilibrium, let's suppose it's not, and that the informed bank bids in $\left[\bar{r}_{N}, x\right], x i n\left[\bar{r}_{N}, \bar{r}_{B D} \wedge R\right)$, and in $\left[y, \bar{r}_{B D} \wedge R\right.$ ), $\operatorname{yin}\left[\bar{r}_{N}, \bar{r}_{B D} \wedge R\right)$ for $G D$. We show first that there can be no equilibrium with $y \neq x$

When $x<y \leq \bar{r}_{D}$, then the informed can increase profits by increasing $x$, without fear of undercutting by the uninformed. If $y<x \geq \bar{r}_{D}$, the informed can increase profits by increasing $y$. If $y>x \geq \bar{r}_{D}$ the uninformed can just undercut below $y$ to get all defaulting borrowers without loss. the uninformed can undercut and get positive profits. If $x>y \geq \bar{r}_{D}$, then the uninformed can undercut x profitably. If $x>\bar{r}_{D}>y$, the informed can increase profit by increasing y. If $y>\bar{r}_{D}>x$ the uninformed can undercut profitably.

Thus, any equilibrium has to entail $y=x$. Moreover, if $y=x>\bar{r}_{D}$, the uninformed will undercut, and $y=x<\bar{r}_{D}$, the informed can increase profits. Therefore, $y=x=$ $\bar{r}_{D}$. For the informed bank, there are two sources of rents

$$
\pi_{\text {noshare }}^{N}=N_{N}\left(p_{N} r-I\right)\left(1-F_{u}(r)\right)
$$


which are constant across all $r$ on $\left[\bar{r}, \bar{r}_{D}\right]$ and

$$
\pi_{\text {noshare }}^{G D}=N_{G D}\left(p_{G D} r-I\right)\left(1-F_{u}(r)\right)
$$

for every $r$ on $\left[\bar{r}_{D}, \bar{r}_{B D} \wedge R\right)$. BD group yield 0 profits when offered break even, or do not get an offer.

From the first one, plugging in $\bar{r}$ we get

$$
F_{u}(r)=1-\frac{p_{N} \bar{r}-I}{p_{N} r-I}=\frac{\lambda p r-I}{\lambda(p r-I)}
$$

. From the second one

$$
\pi_{\text {noshare }}^{G D}\left(\bar{r}_{D}\right)=N_{G D}\left(p_{G D} \bar{r}_{D}-I\right)\left(1-F_{u}\left(\bar{r}_{D}\right)\right)=N_{G D}\left(p_{G D} \bar{r}_{D}-I\right) \frac{p_{N} \bar{r}-I}{p_{N} \bar{r}_{D}-I}
$$

we get

$$
\begin{gathered}
F_{u}(r)=1-\frac{p_{N} \bar{r}-I}{p_{N} \bar{r}_{D}-I} \frac{p_{G D} \bar{r}_{D}-I}{p_{G D} r-I}=1-\frac{\frac{1}{\lambda}-I}{\frac{\lambda(1-p)^{+}(1-\lambda)}{\lambda(1-p)}-I} \frac{p_{G D} \bar{r}_{D}-I}{p_{G D} r-I}=1-(1-p) \frac{p_{G D} \bar{r}_{D}-I}{p_{G D} r-I}, \\
\pi_{u}(\bar{r})=0=N_{N}\left(p_{N} r-I\right)\left(1-F_{i}^{N}(r)\right)+N_{G D}\left(p_{G D} r-I\right)\left(1-F_{i}^{G D}(r)\right)+ \\
+N_{B D}\left(p_{B D} r-I\right)\left(1-F_{i}^{B D}(r)\right) .
\end{gathered}
$$

To get the expression for $F_{i}^{N}(r)$, note that $F_{i}^{G D}(r), F_{i}^{B D}(r)$ are equal to 0 in $\left[\bar{r}, \bar{r}_{D}\right]$. Thus, in equilibrium, the incumbent bank's strategy for $N$ is characterized by the following cumulative density function:

$$
F_{i}^{G N}(r)=1+\frac{N_{B D}\left(p_{B D} r-I\right)+N_{G D}\left(p_{G D} r-I\right)}{N_{G N}\left(p_{G N} r-I\right)}=\frac{\lambda p r-I}{\lambda p(p r-I)}
$$

over the $\left[\bar{r}, \bar{r}_{D}\right]$.

Similarly, for non-defaulting borrowers we have

$$
F_{i}^{G D}(r)=1+\frac{N_{B D}\left(p_{B D} r-I\right)}{N_{G D}\left(p_{G D} r-I\right)}
$$

\section{Proof of Proposition 2.4}

Under information sharing

For the informed bank, $G D$ group is the only source for informational rents

$\pi_{\text {noshare }}^{G D}=N_{G D}\left(p_{G D} r-I\right)\left(1-F_{u}(r)\right)=N_{G D}\left(p_{G D} \bar{r}_{D}-I\right)=I(1-\lambda)(2 \varphi-1)$

Under no information sharing. 
For the informed bank, there are two sources of informational rents

$$
\pi_{\text {noshare }}=N_{N}\left(p_{N} r-I\right)\left(1-F_{u}(r)\right)=N_{N}\left(p_{N} \bar{r}_{N}-I\right)=I p(1-\lambda)
$$

on $\left[\bar{r}, \bar{r}_{D}\right]$ and

$$
\pi_{\text {noshare }}^{G D}=N_{G D}\left(p_{G D} r-I\right)\left(1-F_{u}(r)\right)
$$

Total informational rents therefore are

$$
\begin{aligned}
\pi_{\text {noshare }}^{N}= & N_{N}\left(p_{N} \bar{r}_{N}-I\right)+N_{G D}\left(p_{G D} \bar{r}_{D}-I\right)\left(1-F_{u}\left(\bar{r}_{D}\right)\right) \\
& =N_{G D}\left(p_{G D} \bar{r}_{D}-I\right)\left(1-F_{u}\left(\bar{r}_{D}\right)\right)=N_{G D}\left(p_{G D} \bar{r}_{D}-I\right) \frac{p_{N} \bar{r}-I}{p_{N} \bar{r}_{D}-I} \\
& =I p(1-\lambda)+I(1-p)(1-\lambda)(2 \varphi-1)
\end{aligned}
$$

\section{Proof of Proposition 2.5}

$$
\begin{gathered}
\pi_{\text {noshare }}^{G D}-c(\varphi-0.5)^{2}=I(1-\lambda)(2 \varphi-1)-c(\varphi-0.5)^{2} \\
\varphi_{\text {share }}^{*}=0.5+\frac{I}{c}(1-\lambda) \\
\pi_{\text {noshare }}^{N}-c(\varphi-0.5)^{2}=I p(1-\lambda)+I(1-p)(1-\lambda)(2 \varphi-1)-c(\varphi-0.5)^{2}= \\
\varphi_{\text {noshare }}^{*}=0.5+\frac{I}{c}(1-\lambda)(1-p) \leq \varphi_{\text {share }}^{*}=0.5+\frac{I}{c}(1-\lambda)
\end{gathered}
$$

\section{Proof of Proposition 2.8}

Let $F^{J}(r)$ denote the c.d.f. of the paid rate for a borrower of $J=G D, N, B D$ - the minimum of the two rates.

Under information sharing,

$$
\begin{aligned}
& F^{G D}(r)=1-\left(1-F_{i}^{G D}(r)\right)\left(1-F_{u}^{D}(r)\right)=F_{i}^{G D}(r)+F_{u}^{D}(r)-F_{i}^{G D}(r) F_{u}^{D}(r), \\
& F^{N}(r)=\bar{r}_{N}=F_{i}^{N}(r)=F_{u}^{N}(r)
\end{aligned}
$$

Under no information sharing,

$$
\begin{aligned}
& F^{G D}(r)=1-\left(1-F_{i}^{G D}(r)\right)\left(1-F_{u}(r)\right)=F_{i}^{G D}(r)+F_{u}(r)-F_{i}^{G D}(r) F_{u}(r), \\
& F^{N}(r)=1-\left(1-F_{i}^{N}(r)\right)\left(1-F_{u}(r)\right)=F_{i}^{G D}(r)+F_{u}^{D}(r)-F_{i}^{G D}(r) F_{u}(r) .
\end{aligned}
$$


Finally, $F^{B D}(r)=\min \left\{\bar{r}_{B D}, F_{u}(r)\right\}$ or $F^{B D}(r)=\min \left\{\bar{r}_{B D}, F_{u}^{D}(r)\right\}$ under information sharing.

Under information sharing, observe above $F_{i}^{N}(r)=F_{u}^{N}(r)=\bar{r}_{N}$ and thus does not depend on $\varphi$.

For the informed bank

$$
\begin{gathered}
F_{i}^{G D}(r)=1+\frac{N_{B D}\left(p_{B D} r-I\right)}{N_{G D}\left(p_{G D} r-I\right)}=\frac{\lambda p(1-p) r-(\lambda(1-p)+(1-\lambda))}{\lambda \varphi p(1-p) r-(\lambda \varphi(1-p)+(1-\lambda)(1-\varphi))} \\
\frac{\partial F_{i}^{G D}(r)}{\partial \varphi}=\frac{-(\lambda p(1-p) r-(\lambda(1-p)+(1-\lambda)))(\lambda p(1-p) r-(\lambda(1-p)-(1-\lambda)))}{(\lambda \varphi p(1-p) r-(\lambda \varphi(1-p)+(1-\lambda)(1-\varphi)))^{2}}
\end{gathered}
$$

So,

$$
\frac{\partial F_{i}^{G D}(r)}{\partial \varphi}=\frac{-\left(\lambda^{2}(1-p)^{2}(p r-1)^{2}-(1-\lambda)^{2}\right)}{(\lambda \varphi p(1-p) r-(\lambda \varphi(1-p)+(1-\lambda)(1-\varphi)))^{2}} \leq 0
$$

which is true because $r \in\left[\bar{r}_{D}, R \wedge \overline{B D}\right.$, so that $r>\bar{r}_{D}$, which implies $p r>\frac{1-\lambda+\lambda(1-p)}{\lambda(1-p)}$, which in turn implies $(p r-1)^{2}>\frac{(1-\lambda)^{2}}{\lambda^{2}(1-p)^{2}}$.

For the uninformed bank

$$
F_{u}^{D}(r)=\varphi F_{i}^{G D}(r)
$$

From the above

$$
\begin{aligned}
\frac{\partial F_{i}^{G D}(r)}{\partial \varphi}= & \frac{-(\lambda p(1-p) r-(\lambda(1-p)+(1-\lambda)))(\lambda p(1-p) r-(\lambda(1-p)-(1-\lambda)))}{(\lambda \varphi p(1-p) r-(\lambda \varphi(1-p)+(1-\lambda)(1-\varphi)))^{2}}= \\
& -F_{i}^{G D}(r) \frac{(\lambda p(1-p) r-(\lambda(1-p)-(1-\lambda)))}{\lambda \varphi p(1-p) r-(\lambda \varphi(1-p)+(1-\lambda)(1-\varphi))} \leq 0
\end{aligned}
$$

So

$$
\begin{aligned}
\frac{\partial F_{u}^{D}(r)}{\partial \varphi}= & -\varphi F_{i}^{G D}(r) \frac{\lambda p(1-p) r-(\lambda(1-p)-(1-\lambda))}{\lambda \varphi p(1-p) r-(\lambda \varphi(1-p)+(1-\lambda)(1-\varphi))}+F_{i}^{G D}(r)= \\
& \frac{-F_{i}^{G D}(r)(1-\lambda)}{\lambda \varphi p(1-p) r-(\lambda \varphi(1-p)+(1-\lambda)(1-\varphi))}
\end{aligned}
$$


Therefore,

$$
\frac{\partial F(r)}{\partial \varphi}=\frac{\partial F_{i}(r)}{\partial \varphi}+\frac{\partial F_{u}(r)}{\partial \varphi}-\frac{\partial F_{i}(r)}{\partial \varphi} F_{u}(r)-F_{i}(r) \frac{\partial F_{u}(r)}{\partial \varphi} \leq 0
$$

Finally, remember that

$$
\frac{\partial \bar{r}_{B D}}{\partial \varphi}=\frac{(1-2 \varphi) \lambda(1-\lambda) p(1-p)}{(\lambda(1-\varphi) p(1-p))^{2}} \geq 0
$$

Thus, minimum interest rates for the $B D$ is non-decreasing, too.

Under no information sharing

$F_{i}^{N}(r)=\frac{\lambda p r-I}{\lambda p(p r-I)}$, and is independent of $\varphi . F_{i}^{G D}(r)$ is the same as above.

$F_{u}=p F_{i}^{N}$ on $\left[\bar{r}, \bar{r}_{D}\right]$, and so does not depend on $\varphi$.

$F_{u}^{D}(r)=p+(1-p) \varphi F_{i}^{G D}(r)$ on $\left[\bar{r}_{D}, \bar{r}_{B D} \wedge R\right]$ and so is non-increasing from the above.

Proof for group $B D$ is analogous to information sharing case.

\section{Proof of Proposition 2.9}

$$
E[r]=\int_{\bar{r}}^{R}(1-F(r))+\bar{r}
$$

and is increasing in $\varphi$ because $(1-F(r))$ is increasing in it too.

\section{Proof of Proposition 2.10}

1. This follows directly from proposition 2.1 and 2.3

2. For non-defaulting borrowers, trivially, both banks bid break even rates $\bar{r}_{N}$ under information sharing: this is lower than any other rate on the supports in the two regimes.

3. For defaulting borrowers, The informed bank: a)Bad signal defaulting borrowers, either do not get credit from the incumbent $(\varphi>\bar{\varphi})$, or receive rate $\bar{r}_{B D}=$ $\frac{\lambda(1-\varphi)(1-p)+(1-\lambda) \varphi}{\lambda(1-\varphi) p(1-p)}(\varphi \leq \bar{\varphi})$. In the latter case, remember that $\frac{\partial \bar{r}_{B D}}{\partial \varphi} \geq 0$

b) Good signal defaulting borrowers have the c.d.f, which, by proposition 2.8 implies (weakly) higher rates under information sharing:

$$
F_{i}^{G D}\left(r, \varphi^{\text {share }}\right) \leq F_{i}^{G D}\left(r, \varphi^{\text {noshare }}\right)
$$

The uninformed bank bids $p+(1-p) \varphi_{\text {noshare }} F_{i}^{G D}\left(r, \varphi_{\text {noshare }}\right.$ on $\left[\bar{r}_{D}, \bar{r}_{B D} \wedge R\right]$ 
under no information sharing. The result now follows from the fact that $\varphi F_{i}^{G D}$ is non increasing in $\varphi$ so that $p+(1-p) \varphi_{\text {noshare }} F_{i}^{G D}\left(r, \varphi_{\text {noshare }}\right)>\varphi_{\text {noshare }} F_{i}^{G D}\left(r, \varphi_{\text {noshare }}\right)>$ $\varphi_{\text {share }} F_{i}^{G D}\left(r, \varphi_{\text {share }}\right)$.

4. Overall, from proposition 2.3 and 2.1, probabilities of not-bidding relate as follows

$$
1-F_{u}\left(R, \varphi^{\text {share }}\right) \geq 1-F_{u}\left(R, \varphi^{\text {noshare }}\right)>(1-p)\left(1-F_{u}\left(R, \varphi^{\text {noshare }}\right)\right)
$$

where $F_{u}(R)=1-\frac{p_{G D} \bar{r}_{D}-I}{p_{G D} R-I}$. Thus, while all other borrowers receive at least one offer and accept one, we still have that a bad defaulting borrower is rejected by the incumbent $(\varphi>\bar{\varphi})$, and faces lower chances of receiving any credit from the outside as well under information sharing. Given that banks' overall profits are 0, this is a transfer to the creditworthy borrowers.

\section{Proof of Proposition 2.11}

$$
\operatorname{Pr}(\text { switch })=1-\operatorname{Pr}(\text { stay })
$$

Borrowers stay with probability 1 when the uninformed bank bids strictly higher, and with probability 0.5 when rates are equal. For all mixed strategy cases with general strategy pair $F_{u}(r)$ and $F_{i}(r)$ on $[\underline{r}, \bar{r}]$

$$
\operatorname{Pr}(\text { switch })=1-\int_{\underline{r}}^{b a r r}\left(1-F_{u}(r)\right) d F_{i}(r)
$$

\begin{tabular}{|c|c|c|}
\hline & Sharing & No Sharing \\
\hline Group $N$ & Both bid equal rates $\bar{r}_{N}=>\frac{1}{2}$ & $\begin{array}{l}1-\int_{\bar{r}}^{r_{D}}\left(1-p F_{i}^{N}\right) d F_{i}=p\left(\mid F_{i}^{2}+\int_{\bar{r}}^{r_{D}} F_{i}^{N} d F_{i}^{N}\right) \\
=p-\frac{1}{2} p=\frac{1}{2} p\end{array}$ \\
\hline Group $G D$ & $\begin{array}{l}1-\int_{\bar{r}_{D}}^{R}\left(1-F_{u}^{D}\right) d F_{i}^{G D}=1-1 \\
+\varphi \int_{\bar{r}_{D}}^{R} F_{i}^{G D} d F_{i}^{G D}=\frac{1}{2} \varphi\end{array}$ & $\begin{array}{l}1-\int_{\bar{r}}^{\bar{r}_{D}}\left(1-F_{u}\right) d F_{i}^{G D}=1- \\
\int_{\bar{r}}^{\bar{r}_{D}}(1-p)\left(1-\varphi F_{i}^{G D}\right) d F_{i}^{G D} \\
=p+\frac{1}{2}(1-p) \varphi\end{array}$ \\
\hline Group $B D$ & $\varphi>\bar{\varphi}$, the informed does not bid & $\varphi>\bar{\varphi}$, the informed does not bid. \\
\hline
\end{tabular}

as long as bidding equal rates has measure 0 . For the case with pure strategy bidding $\bar{r}_{N}$ for group $N$ under information sharing, $\operatorname{Pr}($ switch $)=0.5$. Thus,

$\varphi \leq \bar{\varphi}$, from proposition 2.1 it follows that the uninformed bank bids less than $\bar{r}_{B D}$ with probability $\varphi_{\text {share }}$ under information sharing, so borrowers are switching $\frac{1}{2}\left(1-\varphi_{\text {share }}\right)+\varphi_{\text {share }}$. Similarly, under no information sharing and from proposition 2.3 , switching probability will be given by $p+(1-p) \varphi_{\text {noshare }}+\frac{1}{2}(1-p)\left(1-\varphi_{\text {noshare }}\right)=$ $p+\frac{1}{2}(1-p)(1+\varphi)$ 


\section{Conclusions and Discussion}

It might seem intuitive to think that when information is shared via credit bureaus or public credit registers banks will have lower incentives to invest in information collection, lower monitoring or screening, and ultimately, quality of lending decisions and welfare may decline.

Starting from the important distinction between hard and soft information, and the observation that only the former can be transferred through information sharing arrangements, we show that banks will actually invest more in acquiring soft information when hard information is shared. The intuition behind the result is as follows: when hard information is shared, the uninformed bank becomes more aggressive about the good quality transactional customers with no-default in history, and less aggressive about the defaulting borrowers: borrowers in the latter group stay more with the incumbent, who therefore invests more in their type-informativeness. The reason for this is that the defaulting group is on average more risky, and information collection may help reveal many uncreditworthy borrowers and thus avoid losses. As a result, the higher information acquisition will improve the accuracy of lending decisions, increase welfare, and may be particularly useful for small firms that are differentiated along "soft" characteristics. Thus, one of the apparent victims of information sharing - borrowers that require significant investment in information - may actually benefit from the existence of credit bureaus.

Our results obviously present an important argument in favor of information sharing. But they also point to an interesting implication in terms of the structure of the banking system. In particular, information sharing will increase bank's rents from and their focus on relationship lending thus. Moreover, it may widen the gap between small banks relying on collecting soft information and large banks relying on standardized, hard information (Stein 2002, Berger et al. (2005)): indeed, information sharing increases small banks' incentives to collect soft information and makes it easier for large banks to get their standardized data.

There are other aspects of technological progress that are of relevance to the study of information acquisition and information sharing. Boot and Thakor (2000) study the effect of the increasing number of banks on each bank's investment in relationship lending. Unlike our paper, banks have a fixed lending capacity to allocate between relationship and transaction loans. Increasing number of banks hurts the banks' profits from both relationship and transaction lending because each bank has a lower share in the limited borrower population. Since each bank has a fixed capacity, both may shrink. Nevertheless, relationship lending is more protected from interbank competition than transaction lending. Thus, while both shrink, transaction lending shrinks more. Hauswald and Marquez (2003) discuss two technological advances in gathering information - advances in information processing vs. advances in access to information. Advances in information processing, providing the screening bank with more informa- 
tional advantage, will safeguard it from competition allowing to earn rents. Advances in access to that same "hard" information, on the other hand, levels the playing field for banks and erodes their returns due to increased competition.

The findings of our paper emphasize the importance of making the distinction between the various types of information acquired by banks when assessing the welfare effects of information sharing arrangements. This is an area where further research can be helpful in understanding banks and bank competition. 


\section{Appendix B}

\subsection{Dependent Variables}

Source: BEEPS 2002 survey, except where other source is mentioned.

Switch. Definition: Dummy variable that takes value 1 if the firm has answered "yes" to the question in the survey, "Has your firm changed its main bank (the single bank with which your firm has the closest relationship) since 1998?" Possible answers include "yes", "no", "no main bank". 8 percent of the firms report that they have no main bank. We exclude those firms, this leaves us with a sample of 5209 firms.

React. Definition based on answer to the question: "Now I would like to ask you a hypothetical question. If your firm were to fall behind in its bank repayments, which of the following would best describe how you would expect the bank to react?" Possible answers include: 1 . Extend the term of the loan without changing the conditions $(=3)$ 2. Extend the term of the loan but increase the interest rate $(=2) 3$. Begin legal proceedings to take possession of some assets of the firm $(=1)$.

Days. Definition:" How many days did it take to agree the loan with the bank from the date of application?" The mean is 25 while standard deviation is 37 . The output is the robust OLS measure (we also do Poisson regressions, where we have high significance in all columns).

Checking Account. Definition: Dummy variable that takes value 1 if the firm has answered "yes" to the question in the survey," Does your establishment have a checking or saving account".(source BEEPS 2005)

Ccost. Definition: Ccost is cost of finance; higher values indicate higher cost of financing. It equals 4 , if cost of finance is reported to be of no obstacle, $3=$ moderate obstacle, $2=$ Minor obstacle, $1=$ No obstacle.

\subsection{Firm Level}

Source: BEEPS 2002 survey.

Soft. Soft measures how protected the borrower is from different non-financial factors. It summarizes answers to 19 questions on non financial problems of growth. The exact question in the survey asks: Can you tell me how problematic are these factors for the operation and growth of your business?. The factors include skills of workers, their education, contract violations by customers and suppliers, among others. Each of the questions is answered on a scale from 1-to 4, where higher values stand for less 
obstacles $(4=$ no obstacle, $1=$ major obstacle). We take the sum of the 19 questions, and divide by $4^{*} 19$. Thus, the variable ranges from 0.25 to 1 , where a value of 1 indicates that the received soft signals about the quality of the borrower, have all been good/favorable (19 answers "no obstacle"). We then take 1 - the value of the variable, so that higher values mean less problems.

Management quality. adds: 1 point if the manager has prior experience in the company, 1 point if the manager is older than 40,1 point if the manager has higher education.

Small firm. Definition: Dummy Variable that takes value 1 if total number of full-time employees is less then 50. Source: s4a2.

Large firm. Definition: Sample of firms that are not small. Source: s4a2.

Transition firm. Definition: Firm was established in the years 19891993. Source: s1a.

Post-transition firm. Definition: Firm was established after 1993. Source: sla.

State-owned firm. Definition: State controlled firm (yes/no). Source: s2b.

Sector. Definition: Mining, Construction, Manufacturing transport and communication, Wholesale, retail and repairs, Real estate, renting and business service, Hotels and restaurants, Others. Source: q2.

\subsection{Country Level}

Source: Brown et al. (2007).

Information sharing. For each year between 1996 and 2004 we compute an index for private credit bureaus and one for public credit registers: 1 point if it exists for more than 3 years; 1 point if individuals and firms are covered; 1 point if positive and negative data are collected; 1 point if $\mathrm{PCR} / \mathrm{PCB}$ distributes data which is at least 2 years old; 1 point if threshold loan is below per capita GDP. We then take the maximum of the index for credit bureaus and public credit registers. We use 19961999 values for the 2002 BEEPS, and 20012003 value for the 2005 BEEPS.

Creditor rights. We take the score from brown et al (2007). A score of one is assigned when each of the following rights of secured lenders are defined in laws and regulations. First, there are restrictions, such as creditor consent or minimum 
dividends, for a debtor to file for reorganization. Second, secured creditors are able to seize their collateral after the reorganization petition is approved. Third, secured creditors are paid first out of the proceeds of liquidating a bankrupt firm. Fourth, if management does not retain administration of its property pending the resolution of the reorganization. We use 19962000 values for the 2002 BEEPS, and 20012003 value for the 2005 BEEPS.

Time to enforce payment. Definition: The time taken to resolve a dispute in which a debtor defaults on a payment equal to $50 \%$ of a countrys per capita GDP. The indicator measures the (log of the) number of days from the moment the plaintiff files the lawsuit in court until the moment of actual payment. We use 2005 value for both surveys, because earlier values are not available.

Foreign bank assets. Definition: The share of banking sector assets controlled by banks with a majority (at least 50\%) foreign ownership. We use 19962000 values for the 2002 BEEPS, and 20012003 value for the 2005 BEEPS.

Av. GDP. Definition: Log of per capita GDP in thousands of US dollars. We use 19962000 values for the 2002 BEEPS, and 20012003 value for the 2005 BEEPS.

Inflation. Definition: average annual growth rate of consumer price index (CPI). We use 19962000 values for the 2002 BEEPS, and 20012003 value for the 2005 BEEPS.

Bank concentration. The fraction of deposits held by the five largest banks: Source Barth et al 2001.

NPL. Share of non-performing loans in total loans: Source, EBRD transition Report.

Bank reform index. A score of 1 represents little change from a socialist banking system apart from the separation of the central bank and commercial banks, while a score of 2 means that a country has established internal currency convertibility and has liberalized significantly both interest rates and credit allocation. A score of 3 means that a country has achieved substantial progress in developing the capacity for effective prudential regulation and supervision, including procedures for the resolution of bank insolvencies, and in establishing hardened budget constraints on banks by eliminating preferential access to concessionary refinancing from the central bank. A score of $4+$ represents a level of reform that approximates the institutional standards and norms of an industrialized market economy. Source, EBRD transition Report. 


\section{References}

Barth, J, G Caprio and R Levine (2001), "The Regulation and Supervision of Banks around the World: A New Database". Brookings-Wharton Papers on Financial Services 4: 183-240.

Bennardo A, M Pagano and S Piccolo (2008), "Multiple Bank Lending, Creditor Rights and Information Sharing". Working Paper 221, Centre for Studies in Economics and Finance, Salerno.

Berger, A, N Miller, M Petersen, R Rajan and J Stein (2005), "Does Function Follow Organizational Form? Evidence from the Lending Practices of Large and Small Banks". Journal of Financial Economics 76: 237-269.

Boot, A and A Thakor (2000), "Can Relationship Banking Survive Competition?". The Journal Of Finance, 55(2): 679-713.

Boot, A (2000), "Relationship Banking What Do We Know?" Journal of Financial Intermediation

Brown, M, T Jappelli and M Pagano (2007), "Information Sharing and Credit Market Performance: Firm-Level Evidence from Transition Countries". Journal of Financial Intermediation.

Cetorelli, N (2004), "Real Effects of Bank Competition". Federal Reserve Bank of Chicago Working Paper 03.

Claessens, S and L Laeven (2004), "What Drives Bank Competition? Some International Evidence". The Journal of Money, Credit and Banking 36: 563-583.

Degryse, H and P Cayseele (2000), "Relationship Lending with a Bank Based System". Journal of Financial Intermediation 9: 90-109.

Doblas-Madrid, A and R Minetti (2009), "Sharing Information in the Credit Market: Contract Level Evidence from U.S. Firms". Working Paper, Michigan State University

Farinha, L and J Santos (2002) "Switching from Single to Multiple Bank Lending Relationships: Determinants and Implications". Journal of Financial Intermediation 11: 124-151.

Fries, S and A Taci (2002), "Banking Reform and Development in Transition Economies". EBRD Working Paper 71. 
Gehrig, T and R Stenbacka (2007), "Information Sharing and Lending Market Competition with Switching Costs and Poaching". European Economic Review , 51: 77-99.

Giannetti, M and S Ongena (2005), "Financial Integration and Entrepreneurial Activity: Evidence from Foreign Bank Entry in Emerging Markets". CEPR Discussion Papers 5151.

Hauswald, R and R Marquez (2003), "Information Technology and Financial Services Competition.". The Review of Financial Studies, 16(3): 921-948.

Hauswald, R and R Marquez (2006), "Competition and Strategic Information Acquisition in Credit Markets.". The Review of Financial Studies, 19(3): 967-1000.

Hogarth, J, E Chris and J Lee, "Why Don't Households Have a Checking Account?". The Journal of Consumer Affairs, 38: 1-34.

Ioannidou, V and S Ongena (2009), "Time for a Change": Loan Conditions and Bank Behavior When Firms Switch". AFA 2008 Meetings Paper.

Jappelli, T and M Pagano (2000), "Information Sharing in Credit Markets: A Survey". CSEF Working Paper 36.

Jappelli, T and M Pagano (1993), "Information Sharing in Credit Markets". Journal of Finance 43: 1693-1718.

Jappelli, T and M Pagano (2002), "Information Sharing, Lending and Defaults: Crosscountry Evidence". Journal of Banking and Finance 26: 2017-2045.

Kallberg, J and G Udell (2002), "The Value of Private Sector Credit Information Sharing: The U.S. Case". In M Miller, Credit Reporting Systems and the International Economy, MIT Press.

Karapetyan, A and S Stacescu (2009), "Information Sharing and Information Acquisition in Credit Markets", WFA 2009 Meetings Paper, CentER Discussion Paper

Love, I and N Mylenko (2003), "Credit Reporting and Financing Constraints". World Bank Policy Research Working Paper 3142.

Norden, L and M Weber (2008), "Checking Account Information and Credit Risk of Bank Borrowers". EFA 2008 Meetings Paper.

Miller, M (2003), "Credit Reporting around the Globe". In "Credit Reporting Systems and the International Economy". MIT Press. 
Nakamura, I (1991), "Commercial bank information: Implications for the structure of banking". Federal Reserve Bank of Philadelphia, WP 92-1.

Ogura, Y, H Uchida (2007), "Bank Consolidation and Soft Information Acquisition in Small Business Lending". RIETI Discussion Papers.

Ongena, S, D Smith (2001), "The Duration of Bank Relationships". Journal of Financial Economics.

Ongena, S, D Smith (2000), "What Determines the Number of Bank Relationships: Cross-country Evidence". Journal of Financial Intermediation.

Padilla, J and M Pagano (1997), "Endogenous Communication among Lenders and Entrepreneurial Incentives". Review of Financial Studies 10: 205-236.

Padilla J and M Pagano (2000), "Sharing Default Information as a Borrower Discipline Device". European Economic Review 44: 1951-1980.

Petersen, M and R Rajan (1994), "The Benefits of Lending Relationships: Evidence from Small Business Data". The Journal of Finance 49.

Petersen, M and R Rajan (1995), "The Effect of Credit Market Competition on Lending Relationships". The Quarterly Journal of Economics 110(2):407-443.

Petersen M, "Information: Hard and Soft". WP 2004.

Puri M, J Rocholl, and S Steffen (2009), "The impact of the U.S. financial crisis on global retail lending,", working paper, Duke University

Schenone, C (2009), "Lending Relationships and Information Rents: Do Banks Exploit Their Information Advantages?" Review of Financial Studies, forthcoming.

Sharpe, S (1997), "The Effect of Consumer Switching Costs on Prices: A Theory and its Applications to the Bank Deposit Market". Review of Industrial Organization.

Sharpe, S (1990), "Asymmetric Information, Bank Lending, and Implicit Contracts: A Stylized Model of Customer Relationships". Journal of Finance 45: 1069-1087.

Sokolyk, T (2009), "Do Banks Reduce Information Asymmetry and Monitor Firm Performance? Evidence from Bank Loans to IPO Firms". Working Paper, University of Wyoming.

Stein, J (2002), "Information Production and Capital Allocation: Decentralized versus Hierarchical Firms". Journal of Finance 57(5): 1891-1921 
von Thadden, E (2004), "Asymmetric Information, Bank Lending and Implicit Contracts: The Winner's Curse". Finance Research Letters 1(1): 11-23.

Uchida, H, G Udell and N Yamori (2008), "Loan Officers and Relationship Lending". Federal Reserve Bank of San Francisco Working Paper Series. 